\title{
La pintura mural del convento de Santa Clara de Asís en Dzidzantún, Yucatán. Generalidades sobre la ejecución de cuatro diferentes etapas
}

\section{The Mural Paintings of the Santa Clara de Asis Convent in Dzidzantún, Yucatán. General Terms of the Different Four Phases of Execution}

Artículo recibido el 25 de junio de 20I5; devuelto para revisión el 2 de marzo de 20I6; aceptado el 5 de mayo de 20I6. http://dx.doi.org/Io.2220I/iie.I8703062e.20I6.IO9.258I

Ana Raquel Vanoye Carlo

Líneas de investigación

Publicaciones más relevantes
Maestra en Historia del Arte por parte de la UNAM. raquelvanoye@ gmail.com

La arquitectura y la pintura mural de los conventos franciscanos del norte de la Península de Yucatán.

"Sobre la historia de la arquitectura de los conventos franciscanos del norte de la Península de Yucatán: desde la llegada de los franciscanos a Campeche en 1544 hasta la construcción del convento de Santa Clara de Asís en 1567", Revista Fronteras de la Historia del ICANH I8, núm. 2 (2013), 213-246.

Resumen Hasta hace muy pocos años sólo era posible caracterizar la pintura mural de los conventos franciscanos del norte de la península de Yucatán como un conjunto pequeño que agrupaba elementos fragmentados y disconexos que exhibían un deterioro gradual y continuo, lo cual dificultaba su documentación y su investigación, en particular, el desarrollo de una propuesta sobre el orden seguido en su ejecución. La aparición de los murales del convento de Santa Clara de Asís cambió este panorama porque constituyen un grupo numeroso de pinturas, la mayoría sin intervenir, distribuidas en diferentes encalados. Estas características facilitaron la identificación y definición de una serie de etapas a las que era posible asociar un orden y organizarlas en una secuencia. La intervención de la pintura mural, en 20II, puso al descubierto otros ejemplos que proporcionaron información que contribuyó a precisar un determinado número de detalles útiles para complementar dicha secuencia. Este trabajo presenta las etapas que integran esta secuencia y los rasgos que caracterizan a cada una de ellas, así como su potencial contribución en los estudios de la pintura mural que albergan otros conventos de la región. 
Palabras clave Pintura mural; franciscanos; Yucatán; Dzidzantún; conventos; arquitectura religiosa.

Abstract Until a few years ago, it was only possible to regard the mural paintings in the Franciscan convents located in the northern Yucatan peninsula as a small set grouping fragmented and unconnected elements, which exhibited, moreover, a gradual and continuous deterioration; this complicated their recording and examination, making it difficult to arrive at a hypothesis regarding the order of the paintings' execution. The finding of the murals in the Santa Clara de Asis convent transformed the panorama since these form a large group of paintings, most of which have never been altered/interfered with, distributed over several different layers of whitewash. These features helped identify and define several phases that were placed in order and sequentially organized. The murals' restoration in $201 \mathrm{r}$ brought other examples to light, providing additional information helpful in pinning down a series of relevant details that complete the classification. The analysis defines the features that characterize each one of the phases in the sequence and the results are an important contribution to the study of mural painting preserved in other regional convents.

Keywords mural painting; Franciscans; Yucatán; Dzidzantún; convents; religious architecture. 
DOI: http://dx.doi.org/10.22201/iie.18703062e.2016.109.2581

ANA RAQUEL VANOYE CARLO

\section{La pintura mural del convento de Santa Clara de Asís en Dzidzantún, Yucatán}

Generalidades sobre la ejecución de cuatro diferentes etapas

$\mathrm{E}$

n el norte de la península de Yucatán no hay muchos conventos franciscanos que alberguen pintura mural. Más aún, en cada uno de estos edificios religiosos hay pocas pinturas y, en ocasiones, sólo fragmentos que no corresponden al mismo mural. Ambos rasgos han dificultado la posibilidad de establecer relaciones incluso entre pinturas que se encuentran en un mismo convento. Esta situación es el resultado de diversos factores ambientales, como la humedad presente en la región, y las circunstancias históricas como la guerra de castas y el proceso de secularización que sufrieron los conventos.

Otro rasgo que caracteriza a la pintura de esta región es que la mayoría es polícroma, a diferencia de otros lugares, como por ejemplo, el centro de México, donde la mayor parte de los conjuntos de murales conservados exhiben la técnica de la grisalla. Por su parte, los murales de la península de Yucatán muestran diversas paletas de color: desde las más limitadas que emplean sólo dos o tres colores hasta las más amplias que incluyen toda la gama.

Además, los murales se han sometido a pocas intervenciones en las cuales han participado algunos restauradores. En la década de los ochenta, la región recibió al primer equipo de especialistas en restauración, encabezado por Miguel Ábrego, quien se encargó de descubrir y estabilizar la pintura mural de 
DOI: http://dx.doi.org/10.22201/iie.18703062e.2016.109.2581

los conjuntos conventuales más representativos de la región como San Miguel Arcángel (1549), en Maní, y Santa Clara de Asís (I567), en Dzidzantún. Por diversas razones, este proceso se interrumpió algunos años, sin embargo, al final de la década de los noventa, la restauración de la pintura mural la retomó Fernando Garcés Fierros, quien se encargó de distintos conjuntos muralísticos de diferentes conventos, proceso que estuvo a su cargo hasta 20Ir. El hecho de que la mayoría de las intervenciones se hayan llevado a cabo por el mismo especialista presenta algunas ventajas: es posible conocer el estilo que caracteriza su trabajo y eliminarlo, en la medida de lo posible, para poder observar y estudiar la pintura original. La uniformidad en los procedimientos es otra de las ventajas con las que contamos, Garcés Fierros, por ejemplo, realizó los respectivos levantamientos fotográficos que documentan el aspecto que tenían los murales antes de su intervención y en sus dictámenes explicó la técnica a la que se sometieron los murales.

A pesar de que en la actualidad es posible visitar y apreciar la gran mayoría de los conjuntos de murales, el acceso a algunos de ellos sigue siendo complicado, éste es el caso de la iglesia de la hacienda de la Blanca Flor, en Campeche, la de San Bernabé, en Pencuyut o de la de San Antonio de Padua, en el poblado de Xocnaceh, lo cual dificulta la documentación de los cambios que estos recintos han sufrido con el paso del tiempo, así como la problemática para someterlos a cualquier estudio prolongado.

Sin duda, el planteamiento del estado actual de la pintura mural del norte de la península de Yucatán revela muchos de los aspectos que aún están pendientes por estudiar; al respecto este trabajo se aboca primero a presentar y describir los murales que sobreviven en el convento de Santa Clara de Asís, en Dzidzantún, pinturas intervenidas durante 20Ir. En la mayoría de los casos el procedimiento incluyó la consolidación de los enlucidos y la reintegración de grandes extensiones de la capa pictórica, lo cual aseguró el aspecto uniforme que actualmente tienen. Por otro lado está relacionado con una característica que dichos murales presentan: antes de la intervención de Garcés Fierros en 2011 muchos mostraban faltantes suficientes en sus enlucidos y en la capa pictórica para determinar que las pinturas no se ejecutaron al mismo tiempo y para establecer, en algunos casos, un orden de elaboración, la paleta de color empleada, el tema representado y las decoraciones preferidas.

El aspecto uniforme de la pintura mural actual es razón suficiente para investigar su apariencia anterior y para tratar de reconstruir el orden de su ejecución. La documentación y comprensión de un orden, al menos parcial, en 
la ejecución de la pintura mural de este convento, constituye un punto de partida para el desarrollo de otros estudios de diversa naturaleza, por ejemplo, los que se centran en aspectos específicos como la iconografía o la función de las pinturas, o aquellos que explican las relaciones o los vínculos con otros conjuntos muralísticos localizados en otros edificios religiosos franciscanos. Además, la cantidad de detalles incluidos en las descripciones también permite emplear estas etapas para inferir algunas características de las decoraciones que, por diversas razones, ya no existen.

En este estudio se analizarán las similitudes entre la pintura del convento de Santa Clara de Asís en Dzidzantún y algunos murales en el ex convento de San Miguel Arcángel, en Maní, con el fin de establecer que la pintura mural que existe en el primer edificio religioso es representativa de la decoración mural de los conventos de la región. Asimismo, se estudiará el parecido que tienen algunos murales del convento de Santa Clara de Asís, en Dzidzantún con algunas pinturas localizadas en diversos conventos del centro de México, por ejemplo, el convento franciscano de San Miguel Arcángel, en Huejotzingo, Puebla, y el agustino de San Miguel Arcángel, en Ixmiquilpan, Hidalgo, con el fin de evitar presentar el caso de la pintura mural franciscana de la península de Yucatán como un fenómeno aislado; finalmente se abordarán algunas explicaciones sobre el significado de los elementos que se reiteran con mayor frecuencia como, por ejemplo, los monogramas y las armas de Cristo, entre otros.

\section{Conjuntos murales}

La mayoría de los conjuntos de murales que sobreviven en los conventos franciscanos del norte de la península de Yucatán son pequeños y fragmentados. Además, debido al clima de la región que presenta altos índices de humedad, muchas de las pinturas muestran un deterioro acelerado y continuo. Estas situaciones hacían casi imposible identificar los temas representados y, en consecuencia, las relaciones existentes entre diferentes escenas localizadas en un mismo recinto, y las características materiales más representativas. Todas estas carencias, en conjunto, impedían determinar los rasgos más generales de la pintura mural de cualquier convento y, en particular, la reconstrucción del orden de ejecución más simple. Esto último limitó la posibilidad de establecer similitudes y diferencias entre pinturas murales pertenecientes a diversos edificios religiosos, por ejemplo, las relativas a los temas y la paleta de 
color. Tampoco era factible comparar fragmentos de murales para encontrar semejanzas ornamentales entre pinturas localizadas en diferentes conventos.

El descubrimiento entre 1983 y $1985^{1}$ de la pintura mural del convento de Santa Clara de Asís, en Dzidzantún, cambió el panorama anterior porque ahí existía un conjunto numeroso de murales. Los fragmentos que faltan hoy día en los muros indican que las pinturas se distribuyeron en diversos encalados, lo cual demuestra su pertenencia a diversas etapas de ejecución además de que sus dimensiones permiten la identificación y determinación de los temas representados, la paleta de color empleada, la ornamentación preferida y las proporciones de las pinturas murales ubicadas debajo de la capa exterior. Todo lo anterior facilitó e hizo posible identificar y definir las etapas que integraron la secuencia.

La intervención de 2011 puso al descubierto nuevas pinturas que proporcionaron información útil para precisar algunos detalles de la secuencia plantea$\mathrm{da}$, relacionados sobre todo con la ornamentación preferida en cada una de las diferentes etapas y con los cambios que experimentó la relación entre la pintura y la arquitectura. Este trabajo se centra en la presentación de una secuencia integrada por cuatro etapas y de los rasgos que caracterizan a cada una de ellas.

Antes de abordar el tema mencionaré que la ornamentación arquitectónica de este edificio religioso es más abundante y de mejor calidad que la exhibida en el resto de los conventos franciscanos de la península de Yucatán. Estas características probablemente se transmitieron también a la pintura mural, por lo cual su factura es más destacada, la cantidad de murales más numerosa o su proceso de renovación más continuo, es decir, las condiciones arquitectónicas del convento de Dzidzantún sugieren que sus murales son un ejemplo de los mejores ciclos pictóricos de la región. De ser así, se desconoce todo lo relacionado con la factura de los ciclos pictóricos de menor calidad, es decir, quizá la pintura mural del convento de Santa Clara centra las investigaciones en el extremo más favorable y beneficiado de la producción muralística, lo cual dificulta la reconstrucción de cualquier situación promedio.

Por último, es importante señalar que Santa Clara de Asís es el único edificio religioso del norte de la península de Yucatán que fue cabecera de doctrina y el cual conserva un número adecuado de murales en buen estado para

I. Entre esos años, Miguel Ábrego llevó a cabo las primeras intervenciones en la pintura mural de los conventos de San Miguel Arcángel, en Maní, y Santa Clara de Asís, en Dzidzantún. Comunicación personal con Miguel Ábrego, técnico restaurador, septiembre de 2013. 
esbozar o reconstruir el aspecto que algunos ciclos pictóricos debieron haber exhibido en la Provincia de San José de Yucatán. ${ }^{2}$

\section{Sobre la localización de la pintura mural}

La pintura mural que se considerará en este trabajo se localiza en el ábside 3 de la iglesia; en las bóvedas de cañón corrido que techan el claustro bajo y los recintos del ala norte; en el vano de la puerta que comunica el claustro con la nave de la iglesia y en el muro sur de la portería del convento (figs. Ia-d). Hasta antes de la intervención de 20II, las diferentes superposiciones de enlucidos y lechadas de cal indicaban que la pintura correspondía a diferentes periodos. Además, la mayor parte no se había trabajado, lo cual permitió identificar algunos aspectos originales que fueron de utilidad para la reconstrucción de una secuencia. ${ }^{4}$

La misma intervención descubrió una serie de pinturas murales sobre las bóvedas de cañón corrido del claustro bajo del convento. Sin embargo, este conjunto no se considera en este estudio debido a que el objetivo principal es organizar en etapas la pintura mural del ábside y mostrar que algunas pinturas murales del convento pueden relacionarse con alguna de ellas.

\section{A propósito de la técnica de las pinturas murales}

Al parecer, en la ejecución de todos los murales del convento de Santa Clara de Asís se empleó la técnica al temple. La observación detenida de los soportes de las pinturas no revela la presencia de tareas, lo cual indica que el enlucido fino se aplicó

2. Con seguridad, en la pintura mural de la Provincia de San José de Yucatán también sucedió lo que algunos autores como Constantino Reyes Valerio han señalado para el altiplano central: "Los estudios que hemos realizado en los conventos que todavía poseen suficientes escenas, nos han permitido percibir que [éstas] no fueron distribuidas al azar sino que, por el contrario los misioneros las distribuyeron con la intención de que sirvieran para enseñar los fundamentos de la doctrina por medio de ellas" (Constantino Reyes Valerio, El pintor de conventos. Los murales del siglo XVI en la Nueva España, Colección Científica [México: Instituto Nacional de Antropología e Historia, I985], II2).

3. A pesar de ser parte del mismo espacio el ábside se refiere a los muros que se encuentran detrás del altar mayor, mientras que el presbiterio al lugar donde se encuentra el altar mayor.

4. Antes de septiembre de 20 II los trabajos de restauración sólo habían avanzado hasta la fase de desencalamiento. Actualmente, las pinturas se han consolidado y reintegrado. 


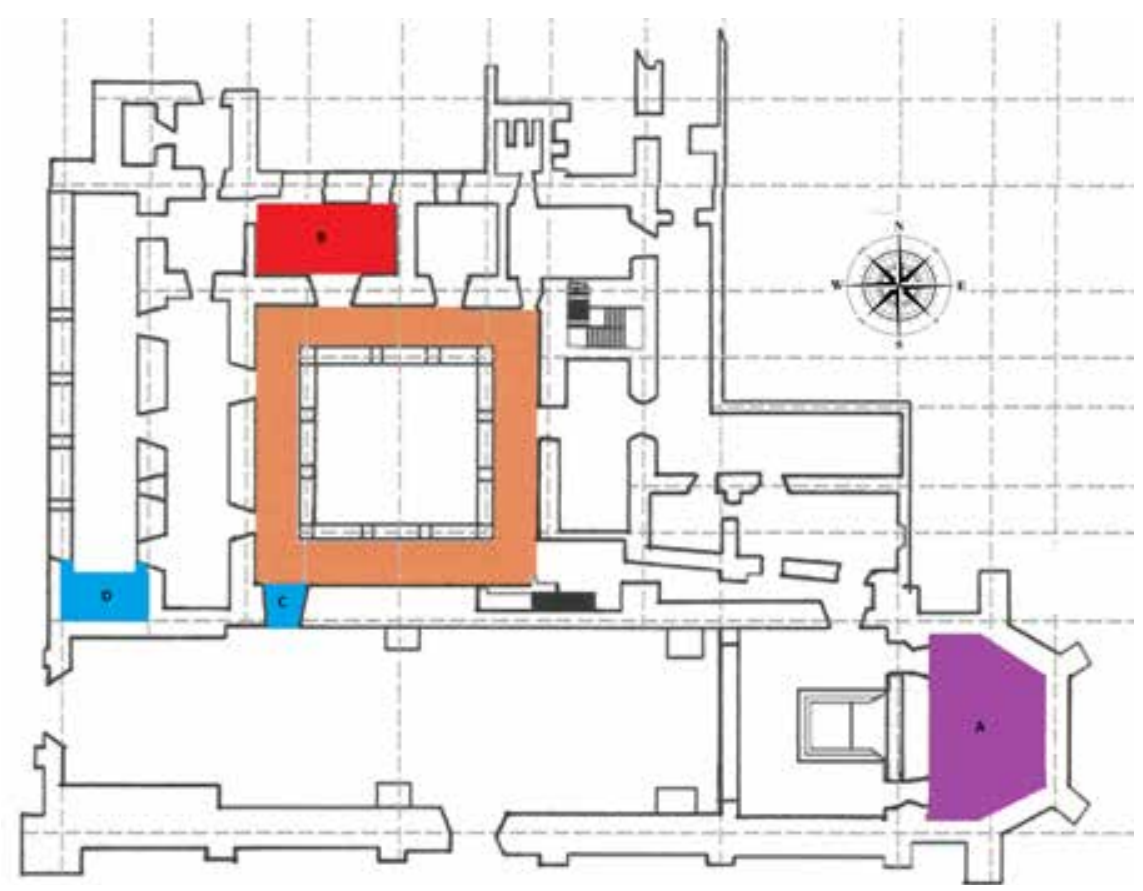

I. Localización de la pintura mural dentro del convento de Santa Clara de Asís, Dzidzantún, Yucatán: a) en el presbiterio de la iglesia; b) en las bóvedas de cañón corrido que techan el claustro bajo y en los recintos del ala norte; c) en el vano de la puerta que comunica el claustro con la iglesia; d) en la portería del convento. Bosquejo de Enrique Sadek-Palazuelos, octubre, 20I5.

sobre el muro antes de comenzar la pintura mural. El bruñido aplicado a este enlucido es otro de los rasgos que también sugieren que se trata de pinturas al temple.

Hasta el momento existen pocos estudios sobre la técnica empleada para ejecutar los murales del convento de Santa Clara de Asís. Sobre este tema, Garcés Fierros, en su "Restauración de la pintura mural de la iglesia de Santa Clara de Asis, de Dzidzantún, Yucatán" incluye una serie de conclusiones obtenidas a partir de "lo que apreciamos en los cortes estatigráficos y en la observación macro y microscópica de los acabados y la pintura mural". 5 Aunque estas afirmaciones aportan información sobre la materialidad de estos objetos,

5. Cuauhtémoc Fernando Garcés Fierros, "Restauración de la pintura mural de la iglesia de Santa Clara de Asís, Dzidzantún, Yucatán”, Archivo de la Coordinación Nacional de Conservación del 
también presentan muchas imprecisiones que deben tomarse en cuenta al momento de considerarlas.

De acuerdo con el restaurador: "el aplanado se efectuó en dos capas, ambas más ricas de cal que las del revoco y con una carga fina. La capa final o segunda es muy delgada y presenta un ligero bruñido". ${ }^{6}$ No todos los encalados tenían estas características sólo los más tempranos. De hecho, entre más reciente fuera el enlucido y mayor el número de revocos que le antecedían, aumentaba la posibilidad de que esta última capa fuera más delgada, y de que, por ejemplo, se construyera usando solamente algunas lechadas de cal. Éste es el proceso evolutivo que distingue a los enlucidos que existen en el ábside de la iglesia del convento de Santa Clara de Asís, por lo cual, el trabajo de Garcés Fierros se refiere sólo a los primeros, sobre los restantes aún no existen estudios.

Respecto a la capa pictórica, el restaurador menciona:

la pintura mural presenta un trazo previo, hecho con grisalla y con diseños incisos, posteriormente se aplicó la pintura con diferentes tipos de pincel y utilizando pintura al temple magro, de proteína, se indica en el estudio que muy probablemente de clara de huevo, por las características de insolubilidad y absorción de agua de la pintura. ${ }^{7}$

El restaurador no incluye los datos del estudio al que hace referencia, pero en el dictamen incorporó una microscopía de tres muestras, lo cual sugiere su existencia. Según la información proporcionada, éstas proceden del retablo del muro 2 incluido en la tercera etapa, por lo cual sólo es posible afirmar que el temple fue la técnica empleada en la ejecución de los murales de este periodo.

Hasta el momento no se han llevado a cabo más estudios de la pintura mural localizada en otras partes del convento.

\section{La pintura mural del ábside de la iglesia}

La mayor parte de la pintura mural que conserva el convento se encuentra en el ábside original de la iglesia actualmente detrás del muro que sostiene el

Patrimonio Cultural-Instituto Nacional de Antropología e Hisotria (en adelante CNCPC-INAH), 4OI.F(2I)IO8.2010/24, 2010, 25.

6. Garcés Fierros, "Restauración de la pintura mural", 25.

7. Garcés Fierros, "Restauración de la pintura mural”, 26. 


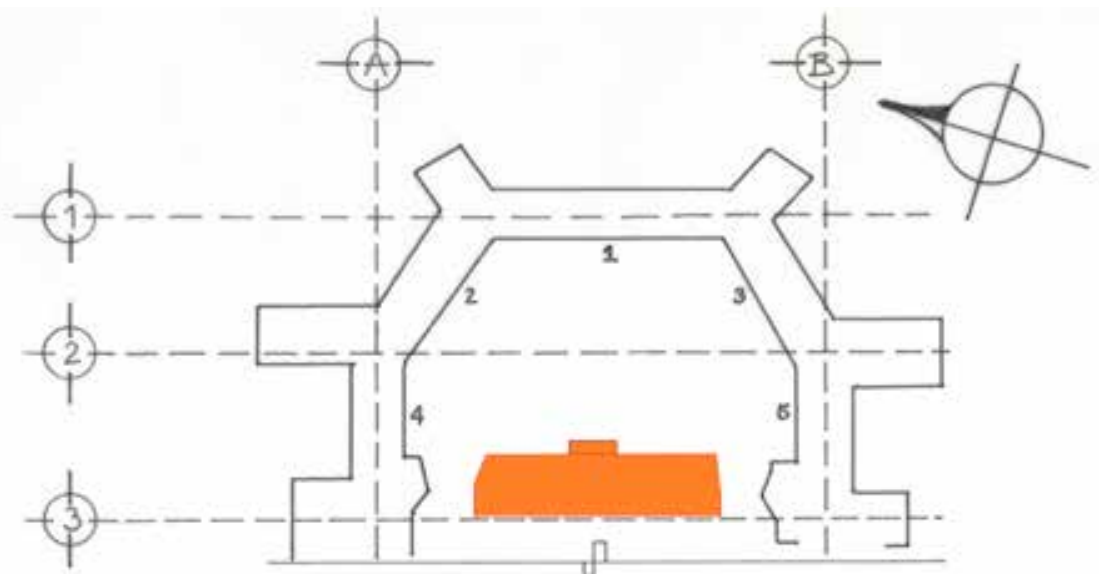

2. Planta del presbiterio original de la iglesia, convento de Santa Clara de Asís, Dzidzantún, Yucatán. La numeración del I al 5 hace alusión a cada uno de los muros del presbiterio de la iglesia. Bosquejo de Enrique Sadek-Palazuelos, octubre, 20I5.

retablo principal (fig. I). En la figura 2 se aprecian los cinco muros que forman esta estructura arquitectónica; los diversos problemas estructurales que presentó la bóveda de lacerías, entre ellos que desde el inicio de su construcción obligaran a los frailes a construir, frente a este ábside y a unos 8 metros de distancia, un muro con su pilastra central para apuntalarla. Esta nueva estructura dividió en dos partes desiguales la nave de la iglesia. El espacio que quedó al oeste, el de mayores dimensiones, siguió funcionando como iglesia y el que quedó al este, de tamańo menor, se utilizó como la sacristía. ${ }^{8}$ La construcción de este muro significó también el aislamiento de la pintura, lo cual, junto con la serie de intervenciones llevadas a cabo por diferentes instituciones y organizaciones, determinó su conservación.

La última de estas intervenciones se llevó a cabo en 2oIr. Ese año, el restaurador Garcés Fierros, adscrito al centro INAH-Yucatán, comenzó el rescate de varias áreas del convento, entre ellas la pintura mural, misma que, de manera general, limpió, consolidó y reintegró. De manera específica, retiró algunos

8. Este lugar albergó la sacristía hasta 20II, año en que los pobladores de Santa Clara de Asís, por instrucciones del presbítero Gabriel Luz Calvillo, rehabilitaron la antigua sacristía, localizada en los recintos del norte de la iglesia. El objetivo era cerrar el espacio localizado detrás del altar mayor y con ello contribuir a la preservación de la pintura mural del ábside. 
encalados de los muros 2, 3, 4 y 5, lo cual le permitió descubrir nuevos murales que hicieron más comprensibles los que ya eran visibles. ${ }^{9}$ La figura 26 muestra el aspecto actual que tiene esta estructura.

La aparición de estos últimos murales fue útil para entender, en el caso de algunas pinturas que anteriormente parecían aisladas, los temas representados, las composiciones elegidas y su relación con el resto del conjunto. La presencia de tales características hizo posible abandonar las explicaciones que privilegiaban las descripciones muro por muro y comenzar a considerar aquéllas en las cuales el ábside se ve como una unidad.

Hasta el momento he identificado cuatro conjuntos de murales que corresponden a cuatro diferentes tipos de decoraciones que el ábside pudo haber exhibido en momentos distintos y que presentaré a continuación. Para introducir los murales que se encuentran en el resto del convento identificaré la probable etapa a la cual pertenecen de acuerdo con los rasgos que comparten con alguna de las decoraciones del ábside, e incluiré su presentación en ese apartado. De este modo, la pintura del antiguo presbiterio funciona como el eje alrededor del cual se organiza el resto de los murales que sobreviven en el convento.

Las pinturas que no caben dentro de alguno de los conjuntos son suficientes para afirmar que esta estructura arquitectónica debió haber albergado otros programas pictóricos cuyo aspecto y determinación de sus características están pendientes para un estudio próximo.

\section{La primera decoración del ábside (I575-I700)}

Las pinturas que pertenecen al primer conjunto se encuentran en los muros I, 2, y 3 del ábside y en la bóveda de lacerías. La figura 27 muestra qué partes permanecen actualmente de los murales de esa época. Con esta decoración sobrevive una mayor cantidad de murales y rastros de pintura. Se trata de un conjunto ejecutado con una paleta que incluye la grisalla y los colores azul y rojo en distintas tonalidades. Éstos se aplicaron sobre enlucidos gruesos y

9. Véase Raquel Vanoye Carlo, "Esbozo de la historia de la pintura mural virreinal de Yucatán", tesis de maestría en Hisotria del Arte (México: Universidad Nacional Autónoma de MéxicoFacultad de Filosofía y Letras, 20II), 35-78; en la sección que corresponde al capítulo 2, titulado "La pintura mural del convento de Santa Clara de Asís", hay una descripción amplia y detallada de toda la pintura mural que era visible en este convento hasta antes de junio de 201 . 
bruñidos de color rosa pálido. ${ }^{\text {Io }}$ Se hicieron en grisalla todos los elementos arquitectónicos que, en general, son de gran tamaño, corren a todo lo largo del muro, y están profusamente ornamentados con motivos vegetales y geométricos, ángeles y monogramas. Su escala indica que una de las características principales de las pinturas correspondientes a esta decoración es su papel preponderante en la configuración de los espacios, pues la arquitectura real queda oculta detrás de la que recrea la pintura. Sobre los tres muros del ábside se pintó un sillar al que interrumpen tres elementos: un retablo mural flanqueado por un par de arcos de medio punto. El retablo de grandes dimensiones es el elemento central de la composición y ocupa casi toda la pared; está coronado por una representación de los símbolos pasionarios ejecutada en el tímpano que remata el muro central del ábside. El autor organizó la composición usando dos estructuras arquitectónicas que enmarcan tres elementos dispuestos verticalmente: una representación de la Coronación de la Virgen es el elemento superior, la escena de la Asunción, el central, y un rectángulo de color crudo, el inferior (fig. 3). La primera estructura (la exterior) está formada por un tímpano, que alberga la escena de la Coronación y que descansa sobre un entablamento apoyado sobre un par de columnas. Dicha estructura funciona como el marco de una segunda, similar en diseńo y composición a la anterior: un frontón curvo que alberga la escena de la Asunción, apoyado también sobre soportes laterales.

Tanto la arquivolta como el entablamento que enmarcan la escena de la Coronación están profusamente ornamentados. Para la primera se alternaron rostros de querubines, con sus alas extendidas, con cartelas apergaminadas. En total hay siete cartelas y seis querubines. Del lado izquierdo hay tres cartelas mientras que del derecho, cuatro: la primera, la cuarta, que además ocupa el lugar central y es ovalada, y la quinta han perdido sus representaciones; en la segunda cartela, sobre un fondo rojo, se pintó, con letras blancas y coronado, el monograma de María (fig. 4a); en la tercera, sobre un fondo negro y con letras rojas, el de Jesús coronado por la letra griega omega (fig. 4b) y, en la sexta se colocó nuevamente, sobre un fondo negro y con letras blancas, el de María, coronado también con la letra griega omega; en

Io. El color de los enlucidos de los conventos franciscanos del norte de la península de Yucatán se debe a algunas sustancias que se agregaron a la cal durante su preparación para mejorar su calidad. También conocido como color crudo, información proporcionada por Rocío Jiménez $(\dagger)$, restauradora adscrita entonces al Centro INAH-Yucatán. Comunicación personal, septiembre de 201 I. 


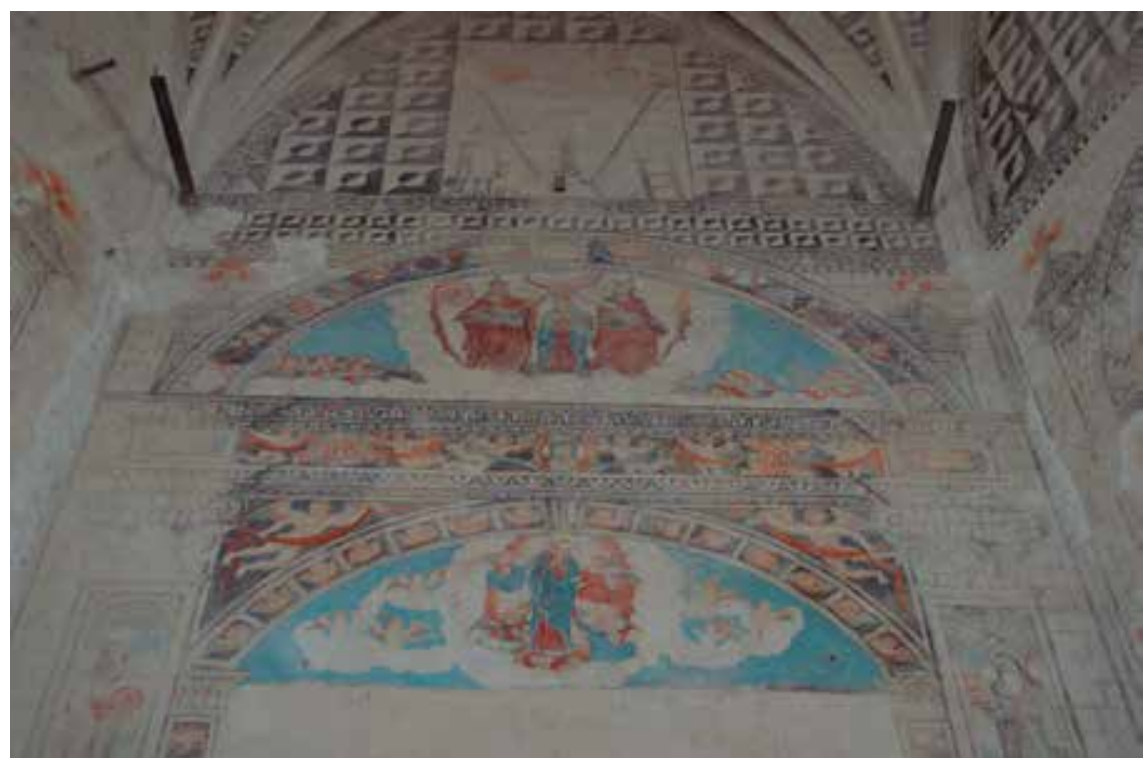

3. Arriba: la Coronación de la Virgen; abajo: la Asunción de la Virgen, muro I, ábside de la iglesia, convento de Santa Clara de Asís, Dzidzantún, Yucatán. Foto: Ana Raquel Vanoye Carlo, julio, 20I3. Secretaría de Cultura-INAH-Méx. "Reproducción autorizada por el Instituto Nacional de Antropología e Historia”.

la última se representó al sol. El pintor colocó un ramo de flores rojas y hojas azules junto a los monogramas de María y una serie de cintas, también rojas y azules que entrelazan las alas de los querubines con las cartelas para sostener estas últimas.

La franja central del entablamento tiene una decoración muy parecida a la de la arquivolta: sobre un fondo negro se pintaron tres cartelas apergaminadas; en la de la izquierda se lee, sobre un fondo rojo claro, con letras color rojo oscuro, el monograma del santo nombre de Jesús coronado con la cruz, la del centro contiene una representación de la Verónica (fig. 4c) y la de la derecha se destinó al monograma de María coronado con la letra omega (fig. 4d). Un par de ángeles con ayuda de listones rojos y azules sostienen cada cartela, estos elementos las atraviesan en distintos puntos y los ángeles sostienen en sus manos los extremos. 
DOI: http://dx.doi.org/10.22201/iie.18703062e.2016.109.2581

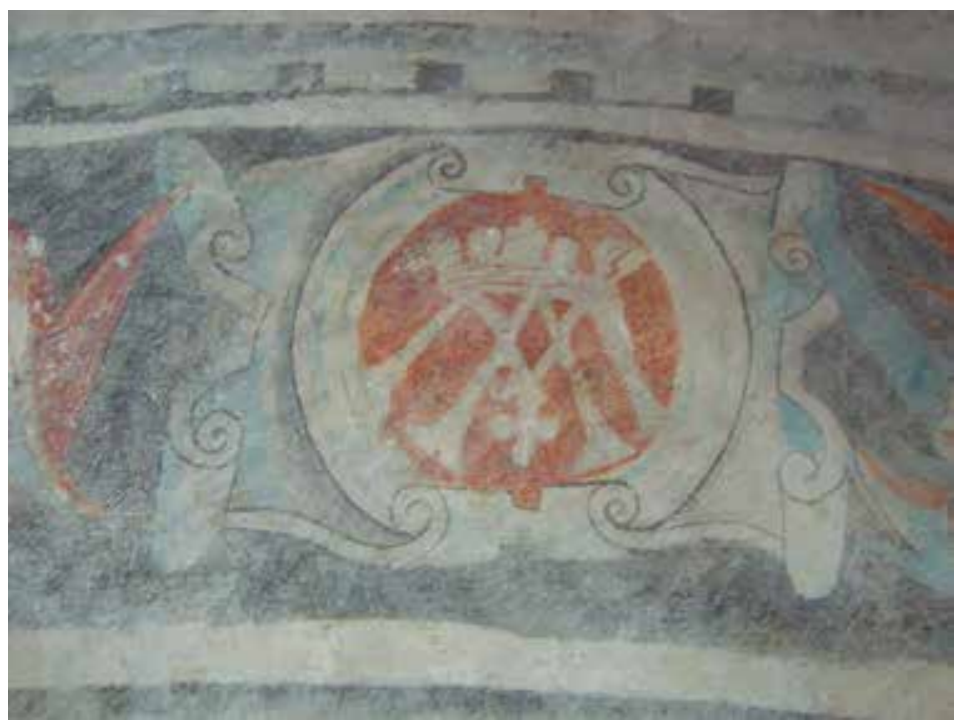

4a) Cartela con el monograma de María coronado en la arquivolta que enmarca la escena de la Coronación. En todos los incisos, muro I, ábside de la iglesia, convento de Santa Clara de Asís, Dzidzantún. Yucatán, junio, 20Ir. Fotos: Ana Raquel Vanoye Carlo.

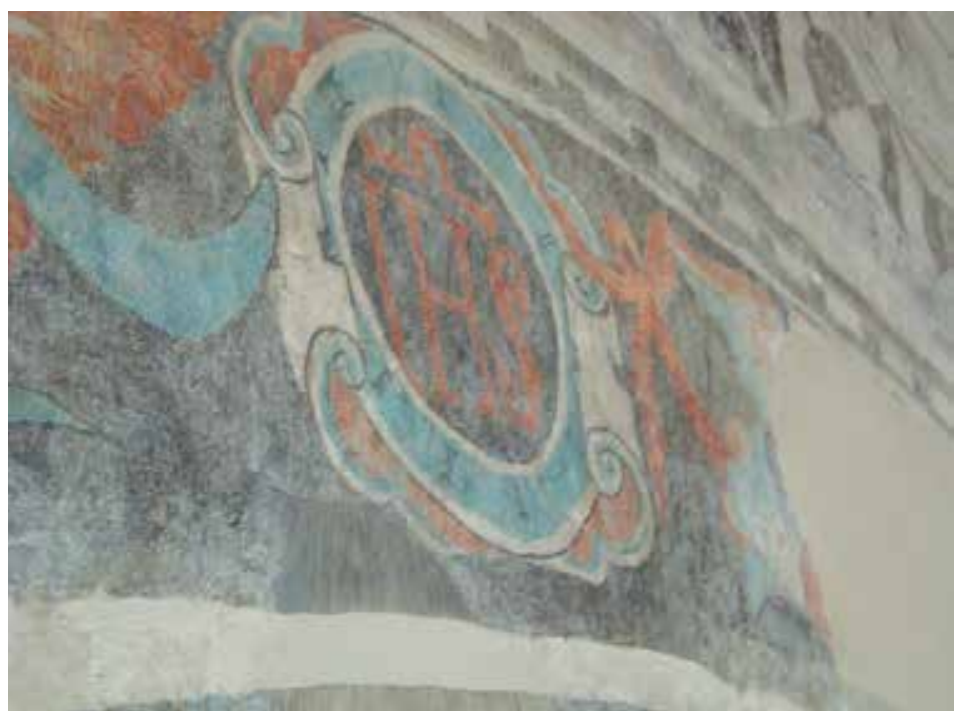

4b) Cartela con el nombre de Jesús en la arquivolta que enmarca la escena de la Coronación. 
DOI: http://dx.doi.org/10.22201/iie.18703062e.2016.109.2581

MURAL DEL CONVENTO DE SANTA CLARA DE ASÍS

4c) Representación de la Verónica en el entablamento que separa las escenas de la Coronación y la Asunción.

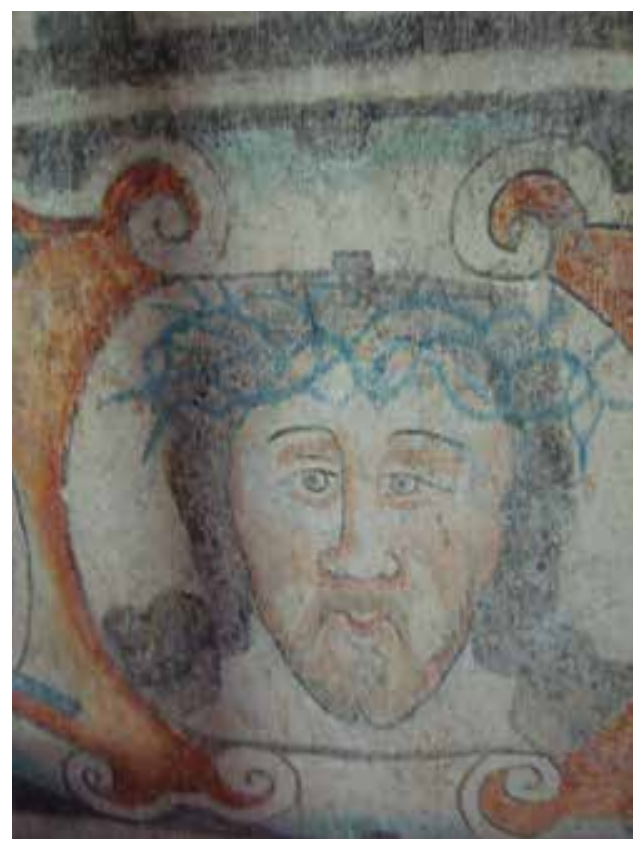

4d) Cartela con el monograma de María, coronado por la letra griega omega, que separa las escenas de la Coronación y la Asunción.

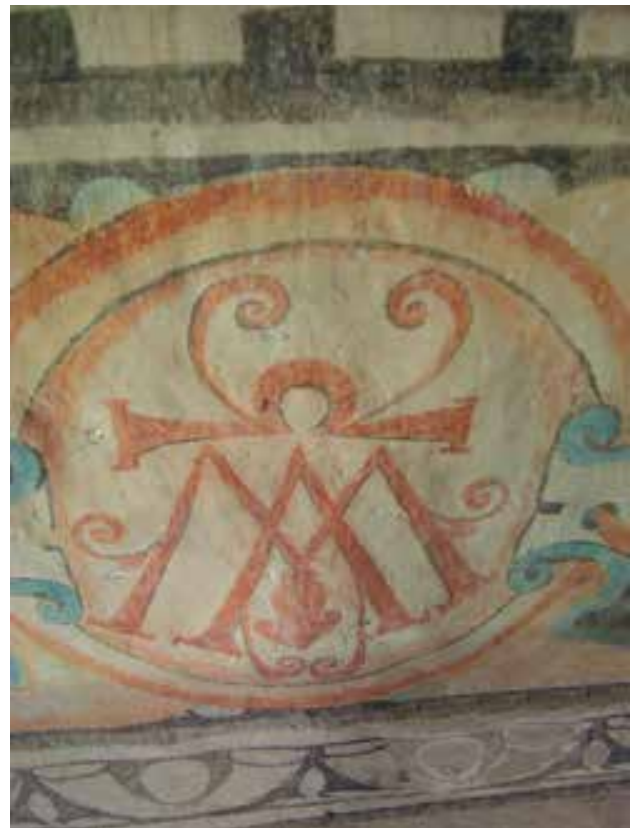


DOI: http://dx.doi.org/10.22201/iie.18703062e.2016.109.2581

Elena Isabel Estrada de Gerlero señala los motivos por los cuales estos monogramas se empleaban frecuentemente como ornamentos de las estructuras arquitectónicas, al respecto señala que:

dentro del convento franciscano, los monogramas de los nombres sagrados estuvieron mayormente visibles a la generalidad de los fieles, en las portadas e interiores de las iglesias y capillas posas de reminiscencias mudéjares y sabor tequitqui, así como en los espacios de clausura conventual de los claustros altos; el monograma simbólicamente reforzará el sentido estructural de las claves de los arcos, encuentro de nervaduras o cerramiento de bóvedas. ${ }^{\text {II }}$

La arquivolta y el entablamento no son los únicos elementos que se decoraron con monogramas: en esta descripción presentaré otros casos que reforzarán esta afirmación respecto de la pintura mural franciscana de la península de Yucatán. En general, el señalamiento de estas similitudes contribuye a construir relaciones entre esta última y la que se localiza en los conventos del resto del país.

Cada una de las columnas que forman parte de la estructura exterior tiene tres nichos. Los santos que ocupan los nichos de la columna izquierda son, de abajo arriba: san Pedro, probablemente san Francisco de Asís y san Bernardino de Siena (fig. 5), mientras que los de la derecha corresponden, considerando el mismo orden, a san Pablo, san Antonio de Padua y santa Clara de Asís. Detrás de los arcos de medio punto y de la escena de la coronación aparecen unas bases que, al parecer son el remate de las columnas, coronadas por la cifra rodeada de rayos solares. ${ }^{\text {I2 }}$

Además de contener la escena de la Coronación, la función del entablamento de la estructura exterior también separa ambas escenas; las enjutas que se forman entre esta estructura arquitectónica y la delgada arquivolta que rodea el momento de la Asunción fueron decoradas, cada una, con un ángel.

II. Elena Isabel Estrada de Gerlero, Muros, sargas y papeles. Imagen de lo sagrado y lo profano en el arte novohispano del siglo XVI (México: Universidad Nacional Autónoma de México-Instituto de Investigaciones Estéticas, 20II), 88.

I2. "San Bernardino de Siena, reformador y vicario general de los observantes, predicó la devoción al Santo Nombre de Jesús a un nivel popular, como una eficaz rama de conversión, e insistió en que sus raíces provenían de la Iglesia primitiva, que comprende tanto la evangélica, como la de los mártires y los confesores. Fue en una de estas ocasiones que se hizo acompañar de la cifra rodeada de rayos solares sobre fondo azul, pintada en una tableta, carente en absoluto de todo vestigio antropomorfista”, Estrada de Gerlero, Muros, sargas y papeles, 79. 


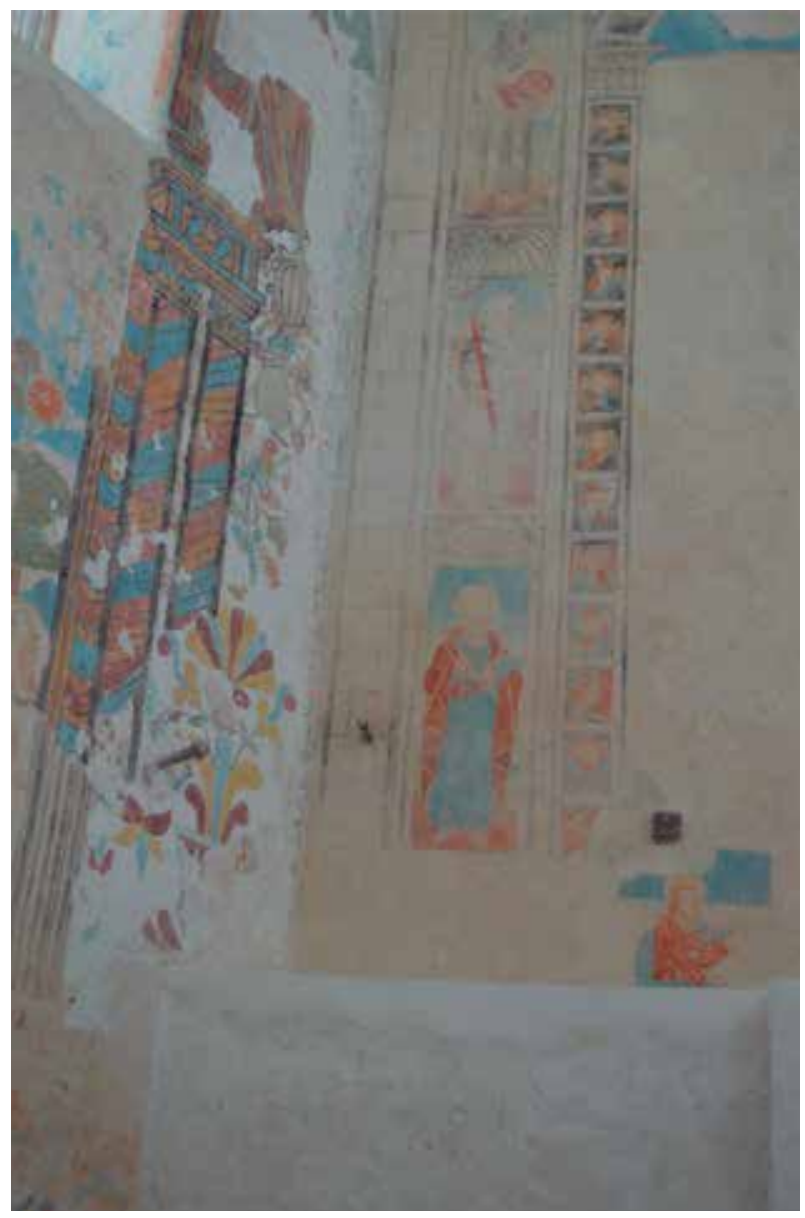

5. De abajo arriba: san Pedro; probablemente san Francisco de Asís y san Bernardino de Siena; a la izquierda: decoración floral correspondiente a la cuarta etapa. En la extrema izquierda se aprecian las arquivoltas que decoran las columnas de la primera decoración y que funcionan como guías de las columnas de los retablos de la tercera decoración, nicho inferior de la columna izquierda del retablo, muro central del ábside de la iglesia, convento de Santa Clara de Asís, Dzidzantún, Yucatán. Foto: Ana Raquel Vanoye Carlo, julio, 20I3. Secretaría de Cultura-INAH-Méx. "Reproducción autorizada por el Instituto Nacional de Antropología e Historia”. 
DOI: http://dx.doi.org/10.22201/iie.18703062e.2016.109.2581

Además, esta arquivolta, que está hecha con sillares decorados, cada uno, con el rostro de un querubín alado, se convierte en las columnas que sostienen el frontón curvo de la estructura interna; todos los elementos anteriores enmarcan el rectángulo rosado cuya característica principal es el nicho que tiene en la parte inferior central. Tal vez, dentro de este espacio se colocaba el Sagrario y sobre el rectángulo un lienzo o un pequeño retablo, o al menos eso es lo que indican las cuatro anclas que se localizan en la parte superior del nicho.

Como ya lo mencioné, a cada lado de este retablo hay un arco de medio punto apoyado sobre un par de pilastras. El arco está decorado con molduras de diferente grosor, la central es la de mayor anchura y está ornamentada con hojas de acanto. En el lugar de la clave se colocaron cartelas que albergan monogramas, para el caso del muro 2 se utilizó el de Jesús y para el 3, el de María. Encima de esta arquivolta central hay dos franjas más: la exterior es un poco más gruesa que la que está en contacto con la central, para decorarlas se emplearon cuadrados negros, equidistantes, dispuestos a lo largo. Por debajo de la franja central hay tres arquivoltas, la relación entre éstas y el capitel indica que están detrás de este último elemento, es decir, no son parte del frente del arco sino de su ancho, por eso se extienden hasta las pilastras. El fuste de estos elementos está ornamentado con un panel rectangular que contiene listones entrelazados. En cada uno de los tímpanos que se forman entre estos arcos y el borde superior de las ventanas, que tienen ambos muros, se colocaron un par de ángeles sosteniendo una cartela.

A continuación describiré la composición del muro 2. Los bordes de la cartela son rojos y lanceolados y en su interior hay un rectángulo de lados azules en el que probablemente se escribió alguna frase en latín aunque, hoy día, sólo puede apreciarse lo que parece una letra $c$ en el ángulo superior izquierdo, debido a que encima se ejecutó otra pintura que abordaré en la tercera etapa. Cada uno de los ángeles está vestido con una falda roja, larga y un blusón azul en cuyo borde se pintó una franja roja, de tono más intenso que el que se empleó en la falda (fig. 6).

La composición que sobrevive en el muro 3 es similar a la anterior, aunque presenta algunas diferencias en su diseño. La cartela tiene los mismos colores pero están invertidos: los bordes lanceolados son azules y el marco del rectángulo es rojo. En el interior, con letras negras, había una leyenda, probablemente en latín, hoy ilegible debido al severo deslavamiento que presenta el mural. Los ángeles que la sostienen están desnudos, cada uno porta un listón 


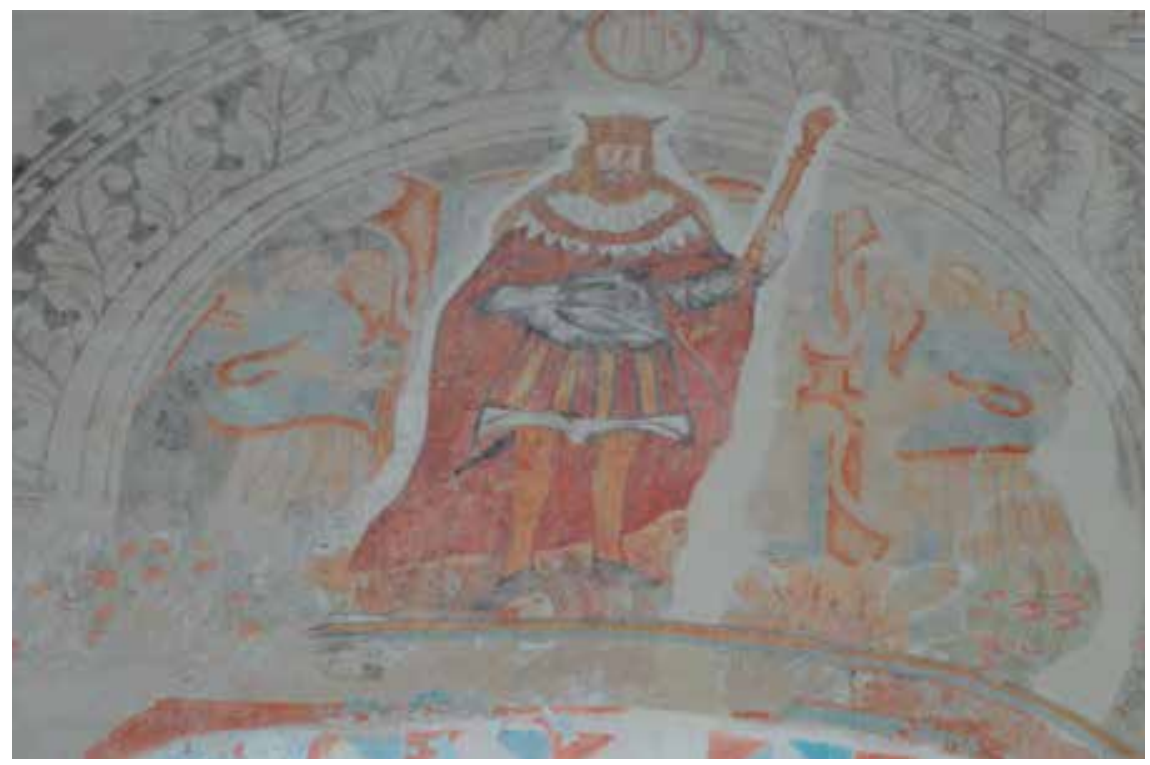

6. Cartela con ángeles tenantes y rey en el remate del retablo, muro 2, ábside de la iglesia, convento de Santa Clara de Asís, Dzidzantún, Yucatán. Foto: Ana Raquel Vanoye Carlo, febrero, 20I5. Secretaría de Cultura-INAH-Méx. "Reproducción autorizada por el Instituto Nacional de Antropología e Historia”.

rojo largo, la parte central de este elemento ha sido colocada alrededor de su cuello, sus dos extremos los cruzaron primero en el pecho del ángel y después lo anudarían en la cintura y caderas, uno de los extremos se entrelaza con la cartela y el otro lo sostienen los ángeles (fig. 7).

Entre las columnas de cada arco y debajo de de cada ventana también había una escena que en ambos casos casi se ha perdido. Para el muro 3, sólo sobrevive la parte superior izquierda de una concha de gran tamaño, en grisalla, rodeada por una franja de cuadrados negros que alterna con otros de color rosa (fig. 2I). Probablemente, coronaba una hornacina parecida en composición a las que se encuentran en el cuerpo de las columnas de la estructura arquitectónica exterior que forma parte del retablo ubicado en el muro central del ábside. El caso del muro 2 es diferente, pues, a pesar del severo deslave que la pintura ha sufrido, aún es posible identificar, en café-rojizo, el rostro, las manos y los pies de san Francisco de Asís y, en gris, su hábito y su cordón. Frente a él hay 
DOI: http://dx.doi.org/10.22201/iie.18703062e.2016.109.2581

236

ANA RAQUEL VANOYE CARLO

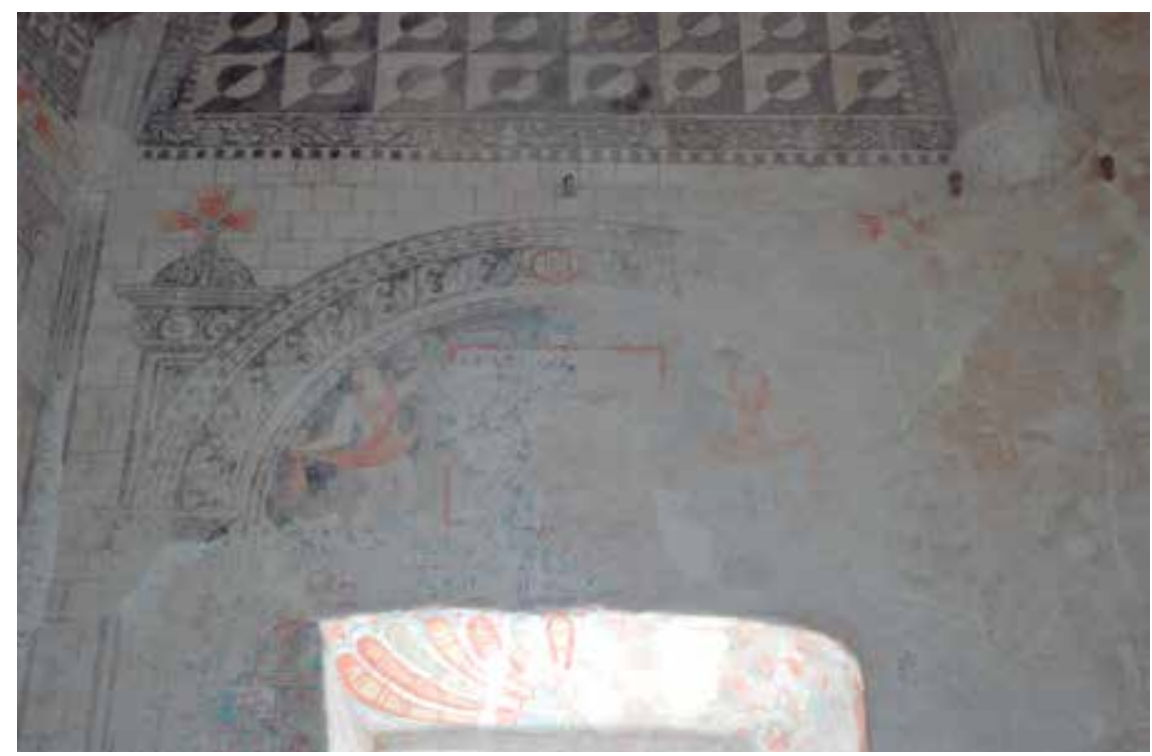

7. Detalle de la cartela con tenantes, muro 3, ábside de la iglesia, convento de Santa Clara de Asís, Dzidzantún, Yucatán. Foto: Ana Raquel Vanoye Carlo, febrero, 2015. Secretaría de Cultura-INAH-Méx. "Reproducción autorizada por el Instituto Nacional de Antropología e Historia”.

un rompimiento de nubes, y detrás un árbol de hojas verdes y frutos sepia (fig. 8a). A su derecha y en la parte inferior se aprecia la silueta de fray León sosteniendo un libro en sus manos. Los elementos anteriores son suficientes para indicar que la escena representada es la de san Francisco de Asís cuando recibe los estigmas. ${ }^{13}$ La línea ejecutada para definir la silueta de ambos franciscanos proporciona información sobre otra de las característica de la técnica: los pintores empleaban una línea café-rojiza para hacer el dibujo preliminar, para esbozar toda la composición, incluso los hábitos, y posteriormente utilizaban el color gris para rellenar los hábitos y cubrir las líneas preliminares, tal y como puede apreciarse en la ropa de fray León. Al final, aplicaban un delineado en negro (fig. 8b).

Como ya lo mencioné, a los lados del retablo y de los arcos es posible apreciar el sillar utilizado para enmarcar estos elementos arquitectónicos, y que se

I3. Comunicación personal, Linda K. Williams, University of Puget Sound, abril de 2013. 
DOI: http://dx.doi.org/10.22201/iie.18703062e.2016.109.2581

MURAL DEL CONVENTO DE SANTA CLARA DE ASÍS

8. a) San Francisco de Asís recibiendo los estigmas; b) detalle de fray León sosteniendo el libro, en la manga del hábito se aprecia la línea café-rojiza, correspondiente al dibujo preliminar, muro 2 del ábside de la iglesia, convento de Santa Clara de Asís, Dzidzantún, Yucatán. Fotos: Ana Raquel Vanoye Carlo, julio, 2012 y 20I3. repectivamente. Secretaría de Cultura unAm-Méx. "Reproducción autorizada por el Instituto Nacional de Antropología e Historia.
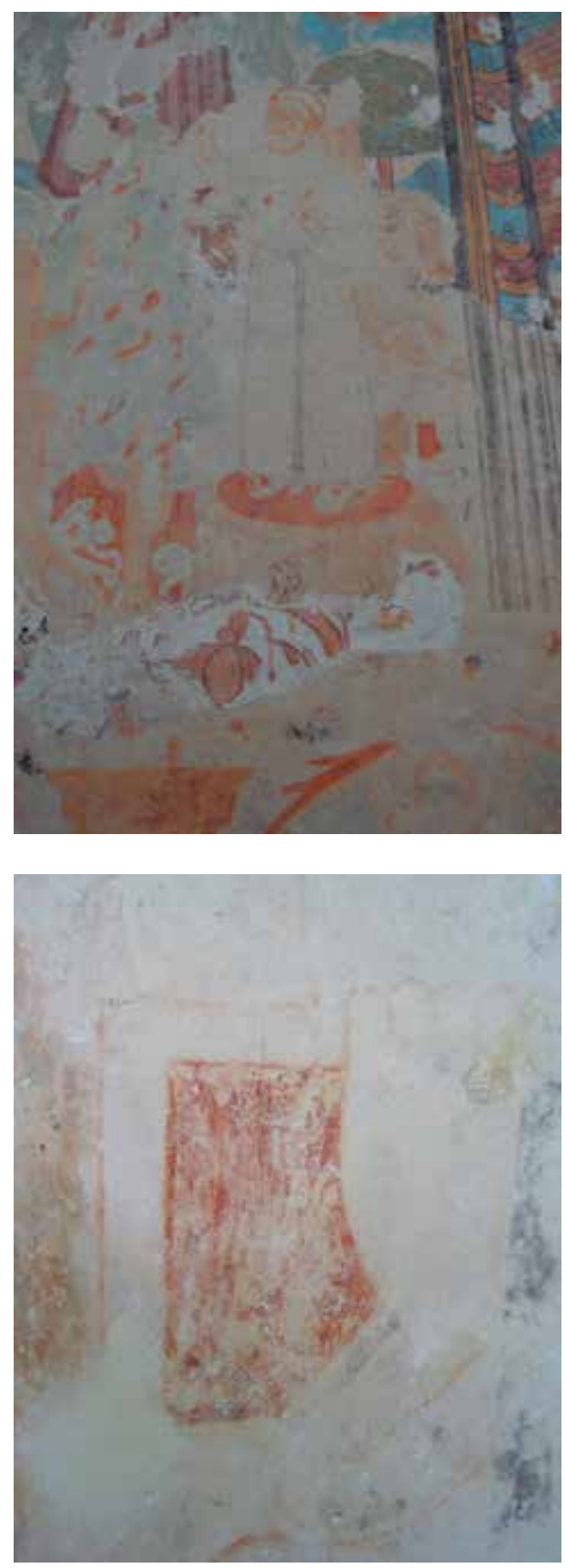
DOI: http://dx.doi.org/10.22201/iie.18703062e.2016.109.2581

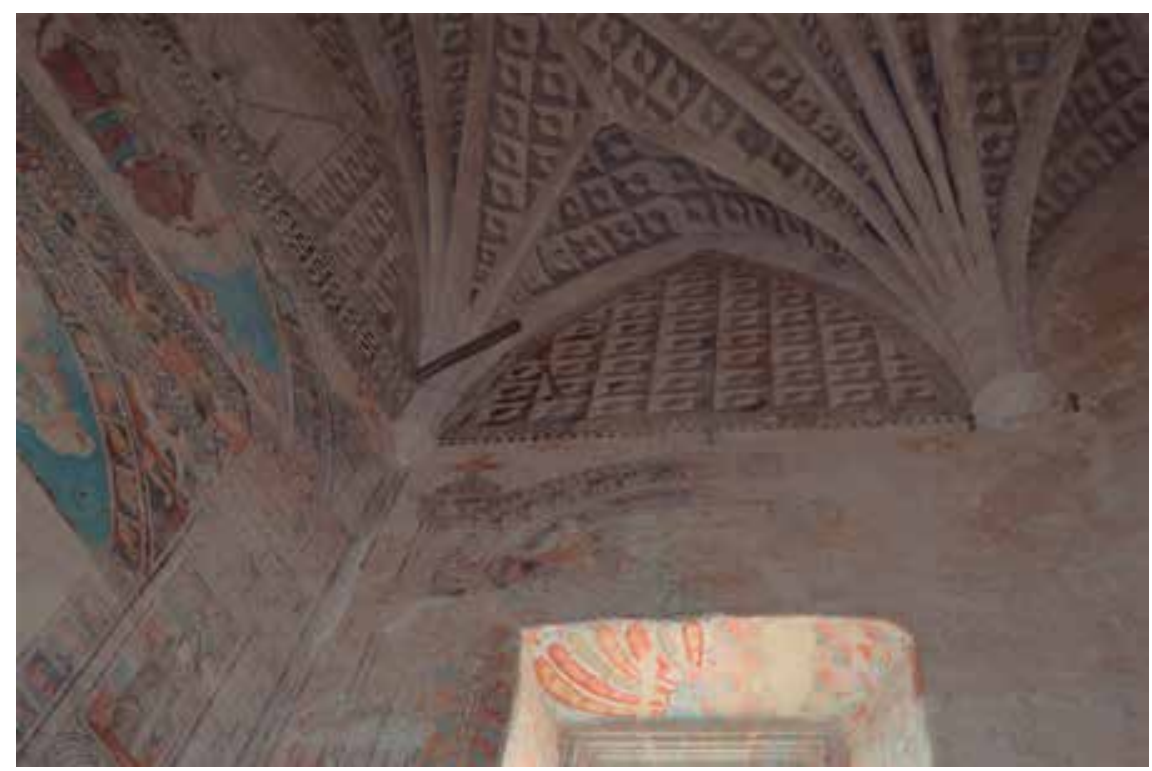

9. Decoración geométrica de los tímpanos y la bóveda de lacerías de la iglesia, muro 3, convento de Santa Clara de Asís, Dzidzantún, Yucatán. Foto: Ana Raquel Vanoye Carlo, julio, 2013. Secretaría de Cultura-INAH-Méx. "Reproducción autorizada por el Instituto Nacional de Antropología e Historia”.

extiende hasta el extremo superior de los muros del ábside, ${ }^{\mathrm{I}}{ }^{4}$ debido a esto, el límite superior de la composición anteriormente descrita es una decoración geométrica que se localiza en los tímpanos y también en la bóveda de lacerías. Se trata de una trama cuyo diseño emplea como unidad un círculo inscrito en un cuadrado (fig. 9), esta ornamentación en general se aplicó con mucha frecuencia para adornar diversas estructuras arquitectónicas como bóvedas, tímpanos y guardapolvos. ${ }^{\mathrm{IS}}$ En la península de Yucatán, el ex convento de

I4. "Son ilustrativos los pasajes de la Retórica cristiana, de fray Diego [de] Valadés, para explicar los grabados acerca de las jerarquías civil y eclesiástica, donde se emplean las imágenes arquitectónicas de origen bíblico: 'la piedra angular' (Cristo), 'las piedras vivas' y las ' piedras cuadradas' (los fieles) que conforman la Iglesia y que son mencionadas por Pedro y Pablo en sus epístolas; de manera que la simulación de sillería [..] para el recubrimiento de parámentos, parece responder a esta necesidad simbólica, ya que los padres de la Iglesia y los liturgistas emplearon frecuentemente dichos símbolos", Estrada de Gerlero, Muros, sargas y papeles, 69.

I5. El diseño de este mosaico es románico, comunicación personal, Elena Isabel Estrada de 


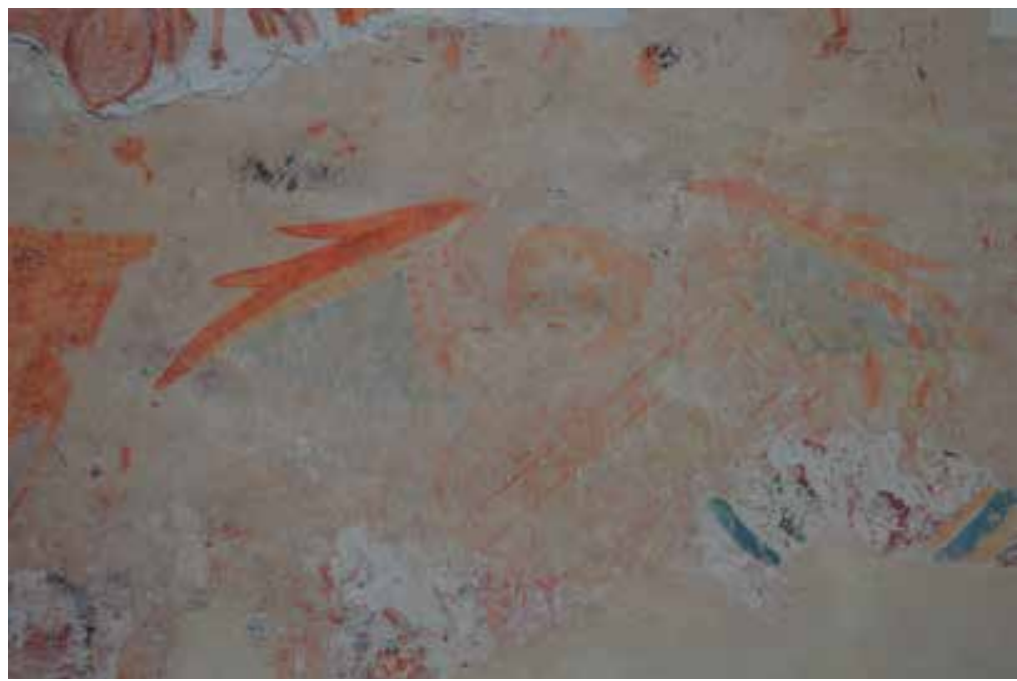

Io. Ángel, borde inferior de la composición del muro 2 del ábside de la iglesia, convento de Santa Clara de Asís, Dzidzantún, Yucatán. Foto: Ana Raquel Vanoye Carlo, julio, 20I3. Secretaría de Cultura-INAH-Méx. "Reproducción autorizada por el Instituto Nacional de Antropología e Historia”.

Maní (I549) también ofrece ejemplos de estructuras arquitectónicas decoradas con esta traza geométrica en la parte superior, como el intradós del arco que comunica la portería con la capilla abierta y la bóveda de cañón corrido que la techa. Una cenefa cierra, por la parte inferior, la composición descrita en los párrafos anteriores, su diseño incluye rostros de ángeles que probablemente sostienen en sus manos instrumentos musicales (fig. IO). Cabe destacar que éstos son los únicos ángeles que exhiben en las alas una franja amarilla que separa la zona superior roja de la inferior azul.

En general, estas pinturas murales presentan suficientes características que permiten afirmar que toda la composición anterior se ejecutó simultáneamente. Por ejemplo, los empates entre las escenas y las estructuras arquitectónicas que las enmarcan, y entre estos últimos y el sillar, la uniformidad y el color rosado de los enlucidos, el uso de una paleta de color similar y los detalles del extremo de las mangas de las ropas que incluyen un doblez. Sin embargo, las diferencias sugieren que no se trató del mismo pintor, probablemente había, al

Gerlero, IIE-UNAM, noviembre de $20 I I$. 
DOI: http://dx.doi.org/10.22201/iie.18703062e.2016.109.2581

240

ANA RAQUEL VANOYE CARLO

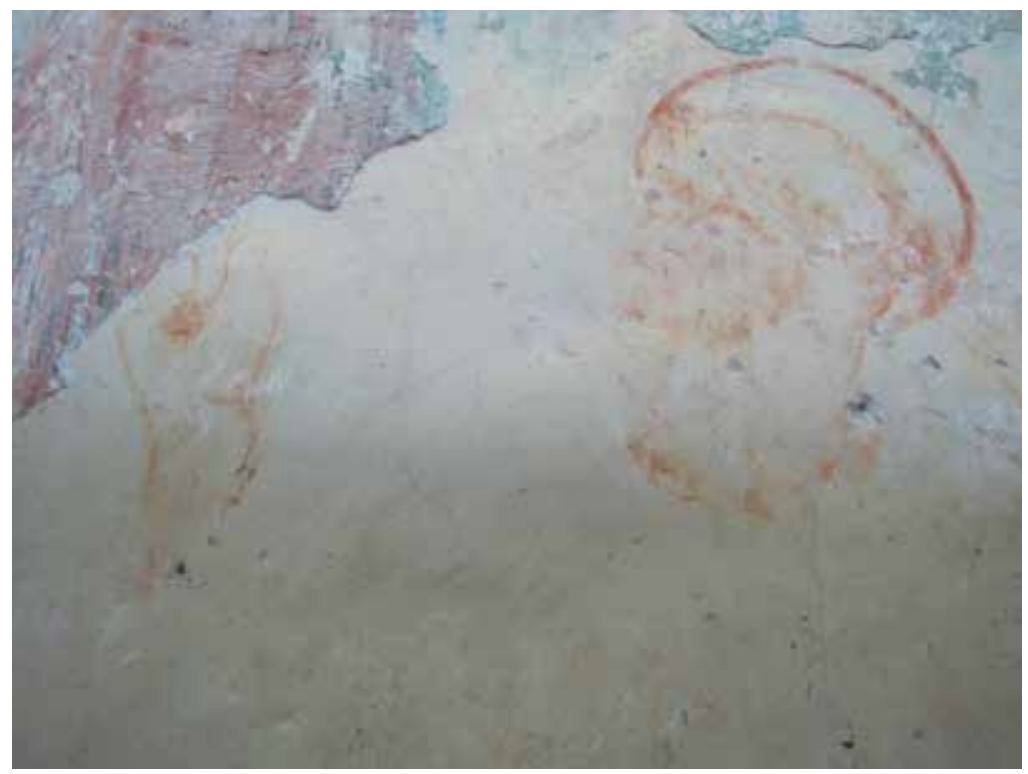

II. Detalle de la figura 8a, brazo izquierdo de san Francisco de Asís que muestra ausencia de pliegues, muro 2 del ábside de la iglesia, convento de Santa Clara de Asís, Dzidzantún, Yucatán, julio, 20I3. Foto: Ana Raquel Vanoye Carlo. Secretaría de Cultura-INAH-Méx. "Reproducción autorizada por el Instituto Nacional de Antropología e Historia”.

menos, dos pintores o equipos de pintores: uno se encargaba de las decoraciones de la superior y el otro de las de la inferior. Entre estas últimas es posible considerar las diversas paletas de color usadas en la ejecución de las alas de los ángeles y en la variedad de facciones plasmadas en los rostros de los personajes (figs. Io y II).

Al parecer, la ornamentación del ábside con retablos murales también fue muy común en la península de Yucatán, tal y como lo sugiere el que decora el ábside de la iglesia del ex convento de San Miguel Arcángel, en Maní (fig. I2). Esta estructura arquitectónica comparte algunas características con la anterior como la paleta de color y diseño, aunque este último es más simple, tal vez se deba a que el ábside sólo tiene tres muros a diferencia del de Dzidzantún que está formado por cinco. Otra característica común es que al retablo mural de Maní también lo corona una representación de los símbolos pasionarios. 
Al igual que en el caso de Dzidzantún, esta escena se encuentra en el tímpano del muro central, sin embargo, su composición es diferente: en Maní, los símbolos están dentro de una pila bautismal (compárese la parte superior de la fig. 3 con la de la fig. I2). Ésta es el elemento central de una cartela apergaminada a la que sostienen dos ángeles, y cuyo borde se dibujó con dos líneas curvas, negras y paralelas entre sí. En algunos fragmentos la línea interior es más gruesa que la exterior, esta característica probablemente representa una sombra que se aplicó para representar la perspectiva. Cada uno de los ángeles viste una falda larga y un blusón, las ropas del de la izquierda son negras y las del de la derecha, azules. En general, el ángel de la derecha está mejor proporcionado que el de la izquierda, ya que las piernas de este último son aproximadamente dos veces su torso y su cabeza. Justo debajo de la pila bautismal, están pintados en rojo, la cartela franciscana de las cinco llagas y a cada lado, el escudo de Castilla y de León. De estos últimos, todavía es posible apreciar los leones, los castillos con sus tres almenas y el cordero que pende del toisón. Al igual que la cartela de los símbolos pasionarios, las almenas y sus ventanas también tienen sombras: la de la izquierda las tiene a la derecha y viceversa. Esta composición es parecida a la que existe en el tímpano del arco de medio punto del muro 2 del ábside de la iglesia de Santa Clara de Asís (compárese la fig. 6 con la I2). Una de las similitudes es la ropa de los ángeles pues en ambos conjuntos éstos visten blusones y faldas largas y, tal vez, las diferencias residan en el contenido de las cartelas y en que el delineado de la representación de Dzidzantún se hizo en azul y rojo, mientras que en la de Maní se ejecutó en azul y negro. La presencia de esta escena en ambos conventos muestra que los temas y la forma de representarlos se difundieron e intercambiaron ampliamente entre ambos edificios religiosos y, quizá, entre todos los conventos de la región.

De hecho, la composición antes descrita se ejecutó con frecuencia en la pintura mural de todos los conventos fundados por los franciscanos en la Nueva España. Por ejemplo, en el claustro del convento de San Miguel Arcángel, en Huejotzingo, Puebla, es posible apreciar este tipo de representaciones, sin embargo, existen amplias diferencias en sus diseños. Para el caso de Puebla, el pintor prefirió emplear cartelas redondas en lugar de apergaminadas, además, la posición de los ángeles sugiere que vuelan mientras sostienen la cartela, en vez de estar de pie. Por último, también difiere la vestimenta, los ángeles del convento de Huejotzingo portan sólo una túnica en lugar del blusón y la falda que visten los tenantes de Maní y Dzidzantún. 
DOI: http://dx.doi.org/10.22201/iie.18703062e.2016.109.2581

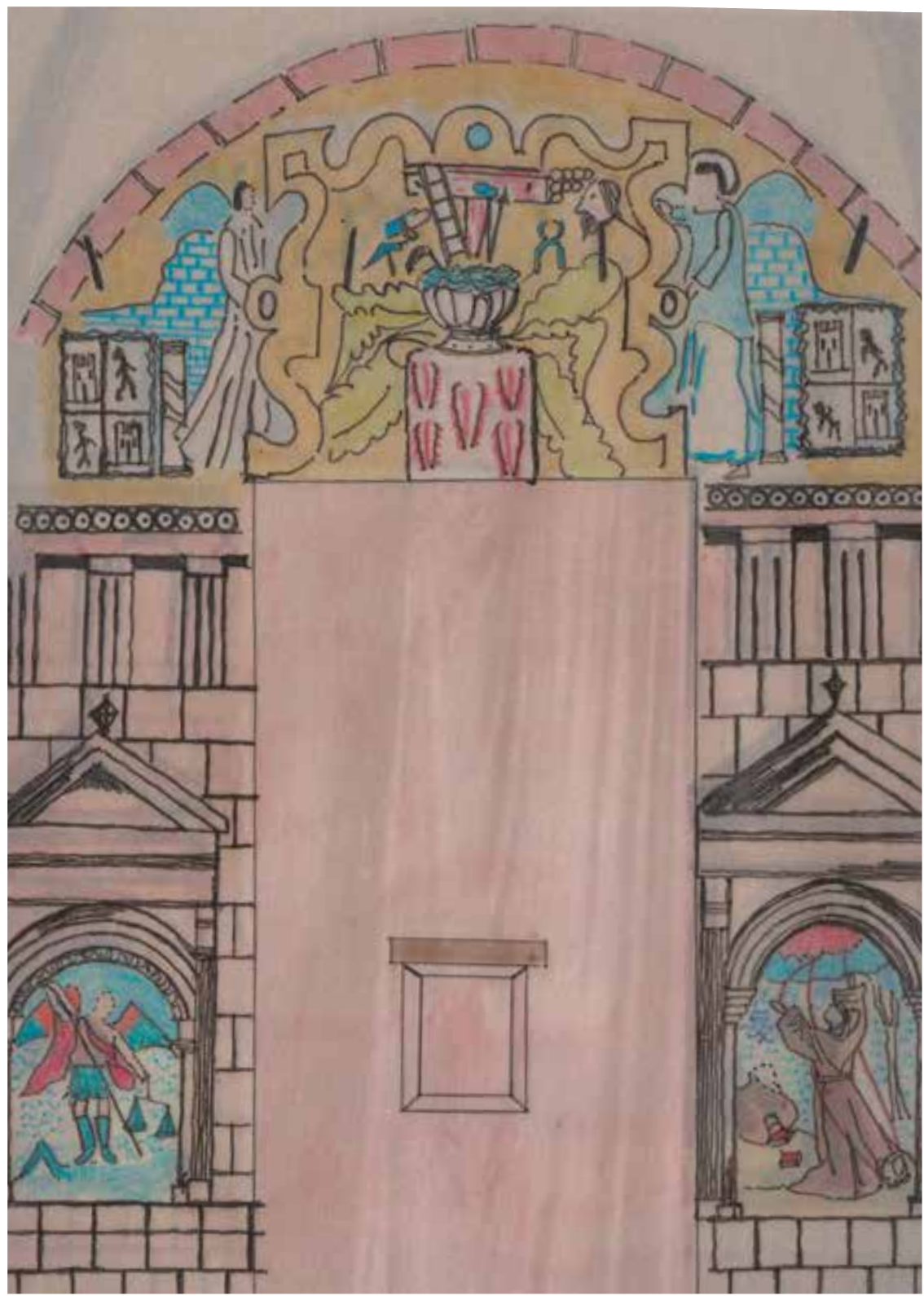

I2. Retablo mural, muro central del ábside de la iglesia, ex convento de San Miguel Arcángel, Maní, Yucatán. Dibujo: Ana Raquel Vanoye Carlo, 2005. 
Sin embargo, la pintura mural del ex convento de Maní presenta algunos elementos adicionales, como los escudos de Castilla y León y la cartela franciscana con los cinco estigmas, además, los símbolos pasionarios se encuentran dentro de la pila bautismal, todo lo anterior sugiere ahondar en el significado de esta representación. ${ }^{16} \mathrm{Al}$ respecto Estrada de Gerlero comenta que a finales del siglo $\mathrm{xv}$ "tuvieron gran difusión en Europa estampas plenas de indulgencias, con el tema de las armas de Cristo, dispuestas heráldicamente dentro de una panoplia como las Armas del Rey de Reyes"17 (fig. I3). Según la autora:

Exactamente el mismo tipo de panoplias fueron representadas en Nueva Espańa en varios conventos principalmente agustinos y en uno dominico, esculpidas en un programa en conjunción a monogramas del Santo Nombre de Jesús, en el claustro de Acolman; pintadas en un muro del aposento y en la parte alta de la [iglesia del convento] de Actopan, del lado de la epístola [...], también en Itzmiquilpan hay una [fig. 14$].^{18}$

Estrada de Gerlero señala que, en algunos de estos ejemplos, el escudo con las armas de Cristo está inscrito dentro de la panoplia y las diferentes insignias en la cresta del yelmo de torneo.

De todos los ejemplos consignados por la autora, la pintura mural de Maní guarda con la representación del convento de San Miguel Arcángel, en Ixmiquilpan, Hidalgo, una gran similitud: en ambos casos la escalera, la cruz, la lanza y la cańa con la esponja aparecen dentro de una pila bautismal y la corona de espinas apoyada en el borde; debajo de ella se encuentra la cartela franciscana con los cinco estigmas. De acuerdo con las afirmaciones de Estrada de Gerlero, la pila bautismal también debe estimarse como un yelmo invertido, bajo esta consideración es posible identificar las tiras lanceoladas ubicadas en la base de la pila como la cresta del yelmo.

Existen otras similitudes entre estas dos representaciones murales. En ambos casos, la disposición de los símbolos pasionarios que están fuera de la pila bautismal es la misma: a la derecha de ésta se colocaron la calavera, las pinzas, los dados, la linterna, las monedas y el rostro de Judas Iscariote, de hecho, algu-

I6. Para hacer posible la comparación véanse dos fotografías del convento de Maní en Vanoye, "Esbozo de la historia", I05 y 106.

17. Estrada de Gerlero, Muros, sargas y papeles, 187.

I8. Estrada de Gerlero, Muros, sargas y papeles, 187. 
DOI: http://dx.doi.org/10.22201/iie.18703062e.2016.109.2581

244

ANA RAQUEL VANOYE CARLO

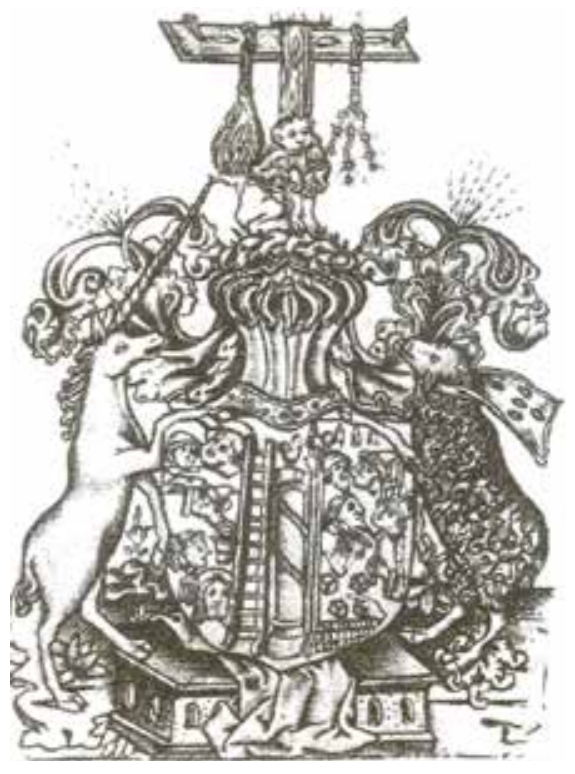

I3. Maestro de la Pasión de Berlín, Escudo de armas con instrumentos de la Pasión, grabado, $9.2 \times 6.7 \mathrm{~cm}$, tomado de Hollstein's German Engravings, Etchings and Woodcuts (I400-I700), ed. Tilman Falk, vol. 24A (Ámsterdam. A. L. van Gendt, 1986), I74.

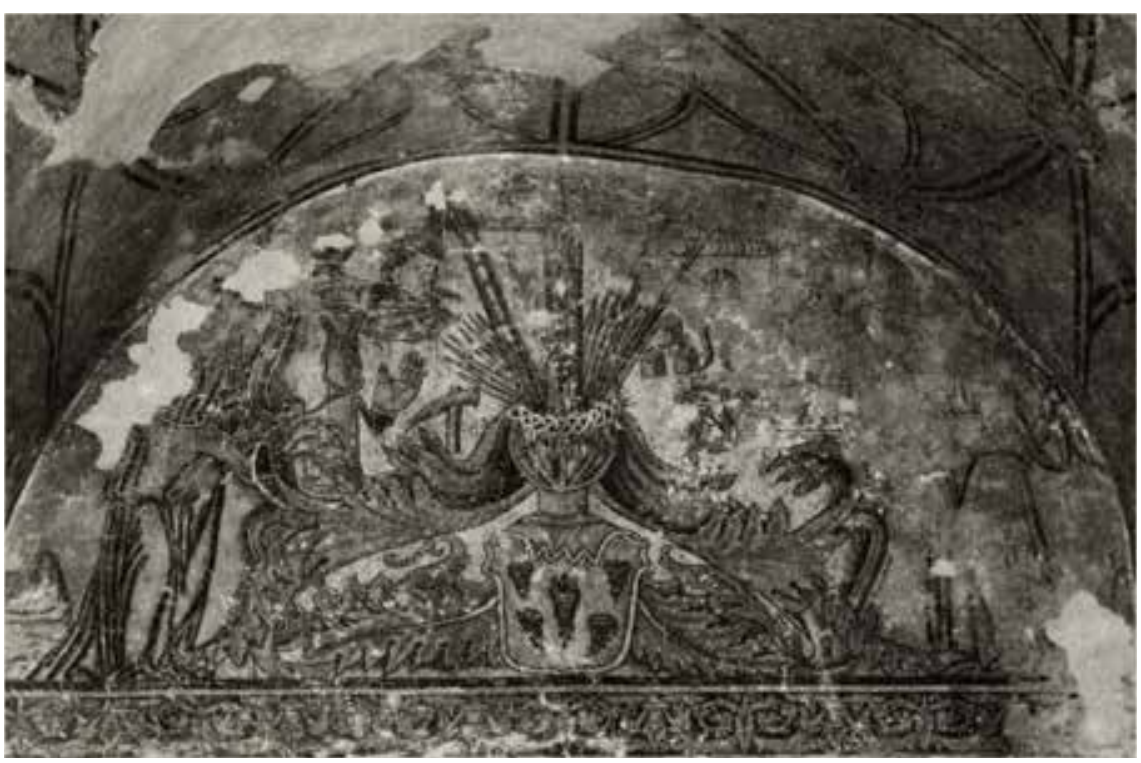

I4. "Panoplia en el paso de ronda, pintura, convento de Itzmiquilpan", así descrito por Elena Isabel Estrada de Gerlero en Muros, sargas y papeles. Imagen de lo sagrado y lo profundo en el arte novohispano del siglo XVI (México: Universidad Nacional Autónoma de México-Instituto de Investigaciones Estéticas, 20II), 192, de donde se tomó la imagen. 
nos de estoselementos también tienen el mismo diseño, por ejemplo, las monedas que, en ambos casos se han pintado en hilera y sobrepuestas. En el lado izquierdo se representaron: el gallo sobre la columna, la mano, el martillo y el rostro de san Pedro. La existencia de la misma iconografía en dos conventos tan distantes es prueba contundente de que todas las actividades relacionadas con la pintura mural estaban planeadas y se ponían en marcha de manera conjunta y organizada y demuestra que la información, así como las investigaciones que hasta el momento se han desarrollado para la pintura mural de los conventos que se localizan en el centro de México se puede utilizar para los que se localizan en el sureste mexicano.

Por último, es importante mencionar que los estudios sobre la pintura mural del ex convento de Maní son escasos. La mayoría de los textos sobre esta escena sostienen que, sin duda, un indígena debió ejecutarla debido a la "ingenuidad de sus rasgos". ${ }^{9}$ Actualmente hay un consenso que indica que la calidad de la representación no es suficiente para determinar cualquier rasgo del pintor, de hecho, para el caso de la pintura mural es conocido que la combinación de la escala y la cercanía necesarias para su ejecución son, en muchas ocasiones, las responsables de distorsiones, sobre todo en las proporciones, que sólo son visibles hasta el final del proceso. Para el caso del mural de Maní, hasta antes de la comparación con la pintura que alberga el convento de San Miguel Arcángel, en Ixmiquilpan, lo único que era posible afirmar era que su autor aún necesitaba entrenamiento.

Sin embargo, el mural de este último convento puede proporcionar información adicional: del lado izquierdo se aprecian las representaciones de dos elementos relacionados con la narrativa de la Pasión: el rostro de san Pedro y la mano. El primero hace alusión al pasaje del Nuevo Testamento en el que Pedro niega conocer a Jesús y el segundo rememora las bofetadas que Jesús recibió como parte de su martirio. Para el caso de Maní, ambos elementos se fusionaron en uno: la mano emerge del cuello de san Pedro; este rasgo pone de manifiesto que el autor del mural tampoco dominaba del todo el relato de la Pasión, por lo cual, muy probablemente se trata de un pintor maya. Antonio de Ciudad Real señaló que el convento de Maní se construyó en sólo seis meses, incluyendo la

19. "La pintura mural localizada en el tímpano representa los símbolos de la pasión, probablemente fue realizada por artistas indígenas dado lo ingenuo o primitivo del dibujo", en Rolando Araujo, "Mural del presbiterio y retablo principal. Criterios de intervención, ex convento de Maní, Yucatán, Maní", Archivo de la CNCPC-INAH, G/3I-047-000/OIN/I, 2002, 3. 
iglesia, por tanto, tal vez este mural se pintó a principios de $1590,{ }^{20}$ y constituye un testimonio del contraste entre la rapidez con la que los mayas aprendieron las nuevas técnicas de ejecución y la serie de problemas que los franciscanos tuvieron que vencer para lograr que los indígenas asimilaran los contenidos de la religión católica y las nuevas formas de representación.

En Maní, como señalado, también hay un retablo mural (fig. I2). Al igual que en el caso de Santa Clara de Asís, se usó una cenefa para separar la escena de los símbolos pasionarios y el retablo mural que tiene un diseño de ovas y dardos. El mismo diseño también se empleó en la franja que separa la pintura del luneto y del muro de la capilla abierta. Esta similitud en la composición no es suficiente para afirmar que las pinturas son contemporáneas, pero lo es para sugerir que una de las actividades relacionadas con la ejecución de la pintura mural era la división de los muros con la finalidad de organizar y distribuir la pintura, y las cenefas eran los elementos asociados a esta actividad. En particular, el empleo de la misma cenefa en la pintura de diferentes recintos indica la intención de los franciscanos de unificar visualmente las decoraciones del convento para que proyectaran unidad visual, es decir, no sólo los temas de la pintura mural anterior se tomaban en cuenta para realizar los nuevos murales, sino que ciertas características como la paleta de color, la composición y los ornamentos también se consideraban en los nuevos diseños.

Como en el de Dzidzantún, la composición del retablo mural de Maní es el resultado de un conjunto de elementos arquitectónicos monumentales que delimitan escenas religiosas. El más visible es un sillar que decora los tres muros del ábside y que está coronado por un friso rematado con metopas y triglifos. En la parte inferior tiene dos nichos: en el de la izquierda se representó a san Miguel Arcángel (fig. I5) y en el de la derecha a san Francisco de Asís recibiendo los estigmas (fig. I6). La composición anterior enmarca un rectángulo central, rosado, que alberga un nicho en la parte inferior central (compárese la fig. 3 con la I2), por lo cual, este retablo mural, al igual que el localizado en el ábside de Santa Clara, funcionaba como el marco de un elemento que se colocaba sobre el rectángulo rosado y que probablemente se trataba de un lienzo, un cuadro o un pequeño retablo.

Las escenas de san Francisco y san Miguel Arcángel están entre una doble estructura arquitectónica: la exterior está formada por un frontón triangular

20. Véase Luis Vega Bolaños, coord., Catálogo de construcciones religiosas del estado de Yucatán, vol. II (México: Talleres Gráficos de la Nación, 1945), 96. 


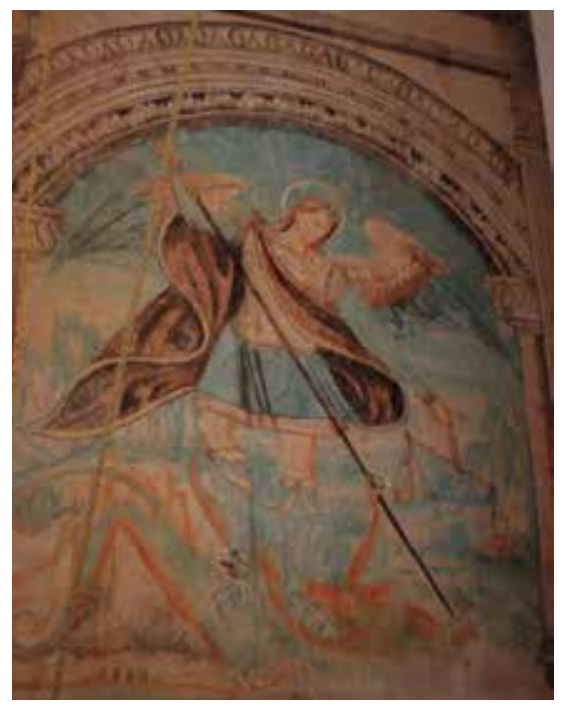

I5. San Miguel Arcángel, muro central del ábside de la iglesia, convento de San Miguel Arcángel, Maní, Yucatán. Foto: Ana Raquel Vanoye Carlo, agosto, 2005. Secretaría de Cultura-INAH-Méx. "Reproducción autorizada por el Instituto Nacional de Antropología e Historia”.

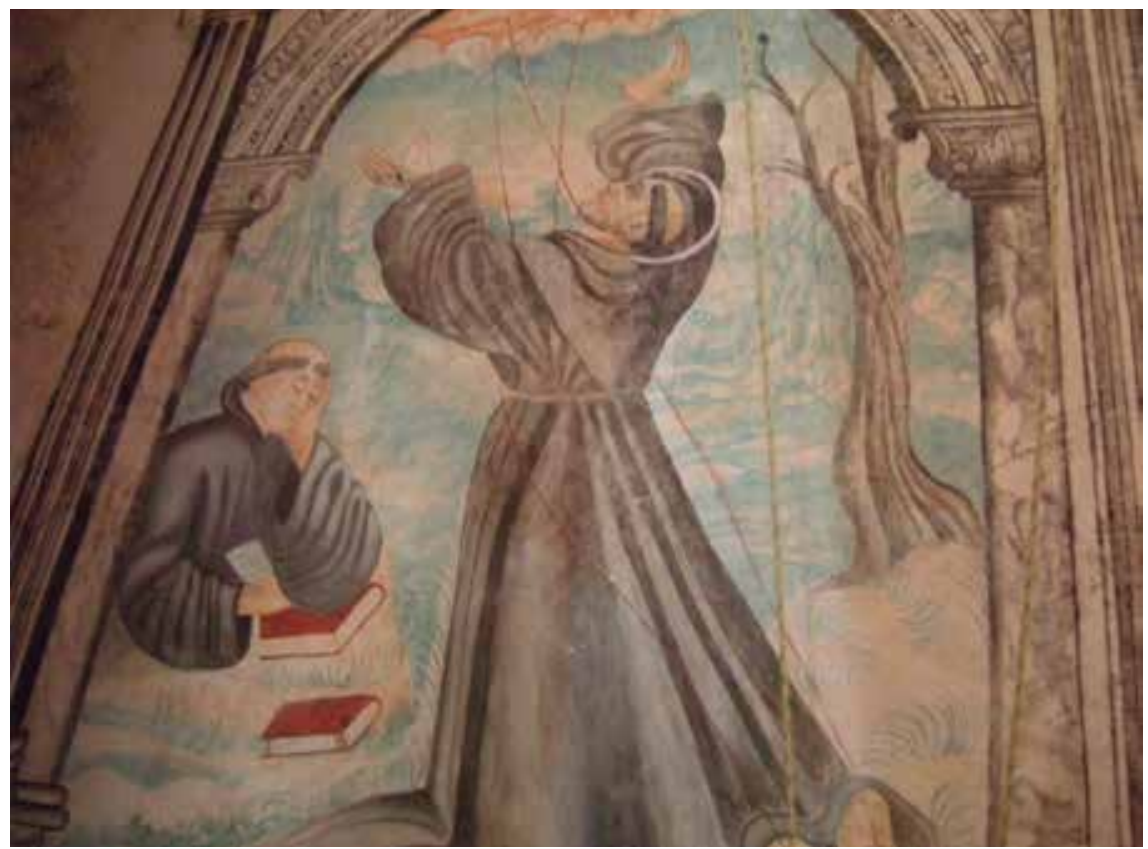

16. San Francisco de Asís recibiendo los estigmas, muro central del ábside de la iglesia, convento de San Miguel Arcángel, Maní, Yucatán. Foto: Ana Raquel Vanoye Carlo, agosto, 2005. Secretaría de Cultura-INAH-Méx. "Reproducción autorizada por el Instituto Nacional de Antropología e Historia”. 
DOI: http://dx.doi.org/10.22201/iie.18703062e.2016.109.2581

248

ANA RAQUEL VANOYE CARLO

apoyado sobre un par de columnas, y la interior es un arco de medio punto que también descansa sobre un par de soportes.

$\mathrm{Al}$ parecer esta pintura se ejecutó sobre un enlucido grueso, rosado y bruñido, o al menos, éstas son las características apreciadas en el rectángulo central y en la bóveda de lacerías que techa el presbiterio, sin embargo, la intensiva reintegración pictórica que las representaciones de san Miguel Arcángel y san Francisco de Asís recibieron junto con la pintura blanca utilizada para rehacer el sillar dificultan la apreciación de otras características que pudieran compartir con las de Dzidzantún. El color empleado en el dibujo preliminar, al cual durante la restauración se le añadió un delineado negro, como en el diseño de los fondos de las escenas, son ejemplo de ello, ya que para el caso de Maní, la parte superior de éstos, la que corresponde al cielo, se reintegró usando unas líneas azules, delgadas y onduladas que no se sabe si corresponden al diseño original. A pesar de estas dificultades, es posible afirmar que las pinturas del muro 2 del ábside de la iglesia del convento de Santa Clara de Asís, en Dzidzantún, fueron el modelo de la composición absidal que decora el presbiterio de la iglesia de Maní.

Posiblemente, en el tímpano del muro central del ábside de la iglesia de Maní se pintó la escena de los ángeles que sostienen una cartela ubicada en el tímpano del arco y en el muro 2, una representación de san Francisco de Asís recibiendo los estigmas (véanse las figs. 6 y 8 a y compárense con la I2 [tímpano] y la I6), que también es el tema planteado entre las columnas que sostienen el arco. No fue difícil decidir quién debía ocupar el otro nicho si recordamos que la advocación del convento de Maní es san Miguel Arcángel.

La posible existencia de una relación entre las composiciones murales de ambos ábsides vuelve a sugerir un intercambio dinámico de temas y modelos de representación en el cual necesariamente estaban involucrados al menos todos los conventos que se encuentran a lo largo del camino y que une estos dos edificios religiosos. La extensión de los conjuntos de murales en grisalla, azul y rojo de ambos conventos indica que esta técnica de ejecución tuvo mucha aceptación. La similitud en los temas, las composiciones y la paleta de color es de utilidad para reconstruir el aspecto que debieron exhibir incluso los edificios religiosos que ya no existen, en particular el convento Grande de San Francisco, de Mérida. 


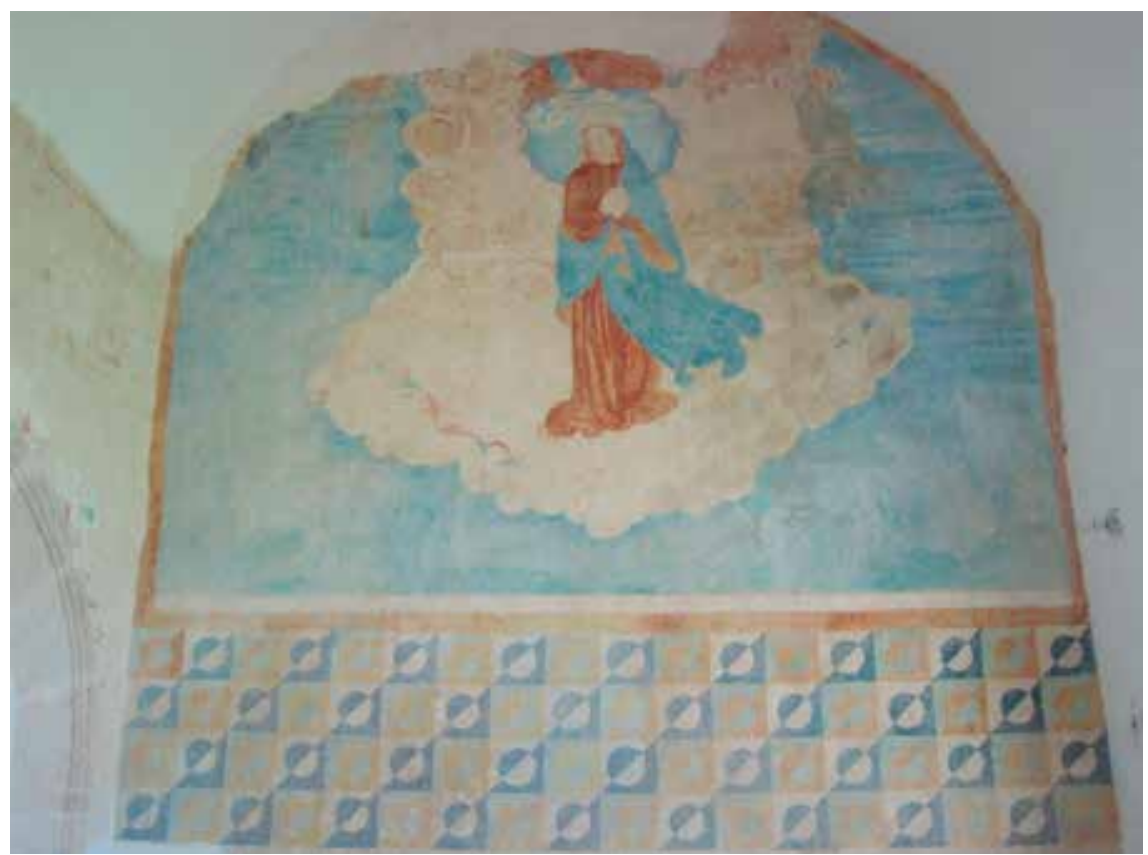

I7. Inmaculada Concepción, muro sur de la portería, convento de Santa Clara de Asís, Dzidzantún, Yucatán. Foto: Ana Raquel Vanoye Carlo, julio, 20I2. Secretaría de Cultura-InAHMéx. "Reproducción autorizada por el Instituto Nacional de Antropología e Historia".

\section{La segunda decoración del ábside (I625-I700)}

La pintura correspondiente a esta etapa se localiza en el ábside (fig. 28, anexo), en la portería (fig. 17) y en el vano de la puerta que comunica el claustro con la iglesia. A pesar de presentarse en un número mayor de recintos que el caso anterior, cuenta con menos murales. Su característica más destacada es la cantidad del punzón en el trazo de algunos elementos geométricos, como los círculos, y arquitectónicos, como las columnas. Hay una disminución drástica en el uso de elementos arquitectónicos, de hecho, sólo se incluyeron en las pinturas del vano de la puerta claustral de la iglesia, sin embargo, su diseño es más complejo que los correspondientes a la etapa anterior (figs. I8 y 19). Además, las pinturas se ejecutaron, en su totalidad, en azul, rojo, blanco y sepia. La manera de aplicar los dos primeros colores es similar a la empleada en la decoración anterior: de forma alterna; una de las principales diferencias respecto 
DOI: http://dx.doi.org/10.22201/iie.18703062e.2016.109.2581

250

ANA RAQUEL VANOYE CARLO

a esa primera decoración es que el uso de esta paleta cromática incluye los elementos arquitectónicos y geométricos.

En el ábside, las pinturas que corresponden a esta decoración se encuentran en los muros 4 y 5 . En el 2 y 3 sólo hay rastros que sugieren su presencia. El central no conserva ningún indicio. En el paramento 4 se aprecia el lado derecho del marco de un caballete, el izquierdo quedó bajo el muro que se construyó para apuntalar la bóveda. El marco tiene cinco franjas. La central es blanca, es la más gruesa y el cordón franciscano la recorre longitudinalmente, y tiene, a cada lado, otras dos más delgadas: las exteriores son rojas y las que están en contacto con ella son azules. Sobre este marco y en el extremo derecho descansa un ornamento sepia que no es posible describir debido al deterioro que presenta.

En el muro 5 se aprecia la parte izquierda de una estructura similar a la descrita en el párrafo anterior. Aunque la escena central e incluso parte del marco de este caballete también se han perdido, sobreviven algunos detalles que proporcionan una idea de cómo debieron haber lucido ambos lienzos: en las esquinas superior e inferior izquierdas se dibujaron rostros de ángeles, flores y copones en colores sepia, azul y rojo. Al parecer, estos elementos funcionaban como una delimitación interna de la escena central. A diferencia del caso anterior, es posible apreciar que el extremo superior izquierdo está decorado con dos cintas sepia entrelazadas (fig. 20).

Debajo de estos caballetes hay rastros de la trama geométrica, la cual consta de círculos inscritos en cuadrados, que en la primera etapa se ejecutó en grisalla, en los tímpanos del ábside y en la bóveda de lacerías; sin embargo, hay tres diferencias importantes: se aplicó en el guardapolvo, está hecha en azul y rojo y se usó un punzón para trazar los círculos. También hay marcas de círculos hechos con este instrumento en los muros 2 y 3 del ábside: se encuentran sobre los rostros de los ángeles que cierran, en la parte inferior, la composición del muro testero que pertenece a la etapa previa, pero no hay rastros del uso de este instrumento sobre los arcos de medio punto, lo cual indica que, probablemente, éstos fueron rescatados e integrados a la segunda decoración. De hecho, el borde superior de la decoración geométrica de los muros 2 y 3 coincide con el borde inferior del retablo del muro I, perteneciente asimismo a la etapa anterior, lo cual indica que quizá este último elemento también lo rescataron e integraron en esta segunda decoración absidal. Este rasgo, la tendencia a no romper drásticamente con el programa pictórico anterior, es otra de las características de este periodo. 
El patrón geométrico, con los rasgos antes mencionados, también se aplicó en el guardapolvo del muro sur de la portería del convento. Arriba, en el luneto, hay una representación de la Inmaculada Concepción (fig. 17). El empate que existe entre la escena y los motivos geométricos sugiere que toda la pintura de este paramento se ejecutó simultáneamente.

La Virgen aparece coronada, vestida con una túnica roja y un manto azul por el anverso y rojo-naranja por el reverso, a sus lados, todavía son visibles, delineados en sepia, el sol, la luna, la torre de David, el espejo sin mancha y debajo de ella un grupo de ángeles dispuestos en forma de luna creciente. Está rodeada de nubes que en la parte superior ofrecen un rompimiento que permite la entrada de un elemento sin identificar y que apareció después de la intervención de 20II. La escena está enmarcada con una línea roja, de unos 5 centímetros de ancho, que sigue la forma del luneto que la alberga.

Las diferencias existentes en las representaciones humanas, que corresponden a la etapa anterior y ésta, refuerzan la idea de que su ejecución se efectuó en momentos distintos. Entre éstas puedo mencionar el tratamiento en la caída de las vestimentas. Para el caso de la primera etapa, los pliegues de las telas se concentran en la parte inferior de las túnicas, mientras que en la segunda, éstos también están presentes en la parte superior de las ropas, incluso se dibujaron los que corresponden a las posiciones flexionadas de los diferentes miembros del cuerpo. Por ejemplo, en la Inmaculada de la portería se aprecian los pliegues de la ropa correspondientes a la postura de sus brazos, a diferencia de los ángeles que sostienen la cartela del muro 2 del presbiterio para los cuales, a pesar de tener los brazos doblados, no se consideró su representación (compárense las figs. 6 y i7). El movimiento de la ropa constituye otra diferencia. En el caso de la Inmaculada, el rompimiento del cielo implica un desplazamiento brusco de las nubes que se refleja en la inclinación y en las orlas de los extremos del manto y la túnica. Al igual que esta escena de la Inmaculada, que corresponde a la de san Francisco de Asís recibiendo los estigmas (muro 2 del ábside, etapa anterior) (fig. 8a), también se representó un rompimiento de nubes, del que probablemente emanaba el serafín quien, según el relato, es el responsable de estigmatizar al fraile; sin embargo, el pintor o pintores de la escena no han podido transmitir los efectos correspondientes de este suceso en la ropa del santo, pues el manto del fraile no presenta inclinaciones, orladuras o pliegues (compárense las figs. II y i7).

El uso de algunos elementos que también aparecen en la etapa anterior, como el círculo inscrito en el cuadrado, la paleta cromática y la forma de emplear los 
DOI: http://dx.doi.org/10.22201/iie.18703062e.2016.109.2581

252

ANA RAQUEL VANOYE CARLO

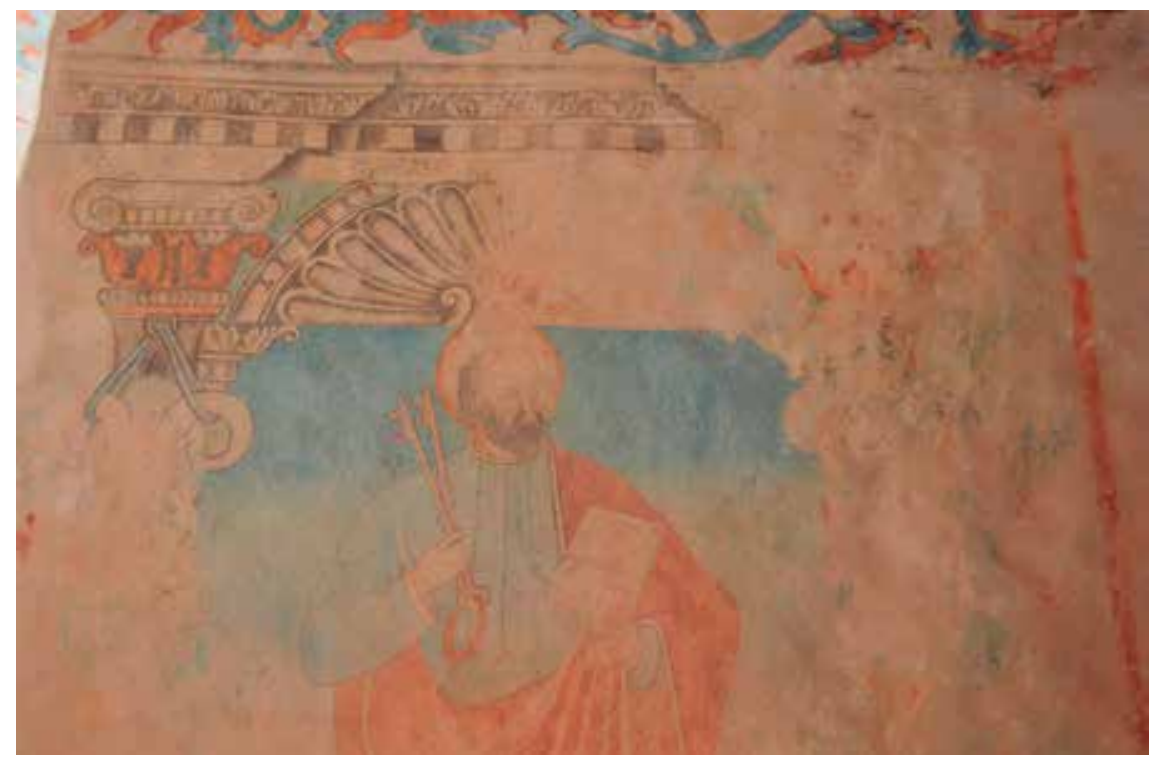

I8. San Pedro, jamba oeste del vano de la puerta que comunica el claustro con la iglesia, convento de Santa Clara de Asís, Dzidzantún, Yucatán. Foto: Ana Raquel Vanoye Carlo, julio, 20I3. Secretaría de Cultura-INAH-Méx. "Reproducción autorizada por el Instituto Nacional de Antropología e Historia”.

colores, refuerzan la idea de que la segunda decoración recuperó algunas características de la primera. Esto vuelve a sugerir que dicha solución ornamental tuvo una amplia aceptación, lo cual motivó el uso continuo y prolongado de algunos de sus recursos. Aunque, otra posibilidad es que los frailes no hubieran podido o querido llevar a cabo la renovación de la pintura mural de todo el convento, por lo cual las nuevas representaciones debían considerar a las anteriores con la finalidad de evitar romper la unidad visual y temática.

Alguna de estas posibilidades determinaron las características que presenta la serie de murales que decoran la puerta claustral de la iglesia; antes de abordarlas, describiré brevemente las escenas que aquí se localizan: en la jamba oeste del vano se pintó un nicho formado por un dintel apoyado sobre un par de columnas balaustradas. Debajo del dintel se aprecia una hornacina avenerada que también descansa sobre las columnas balaustradas. Es san Pedro quien ocupa este nicho: su túnica es azul, su manto rojo y el fondo azul (fig. I8). En la jamba este hay otro nicho que tiene un diseño arquitectónico similar, pero está 


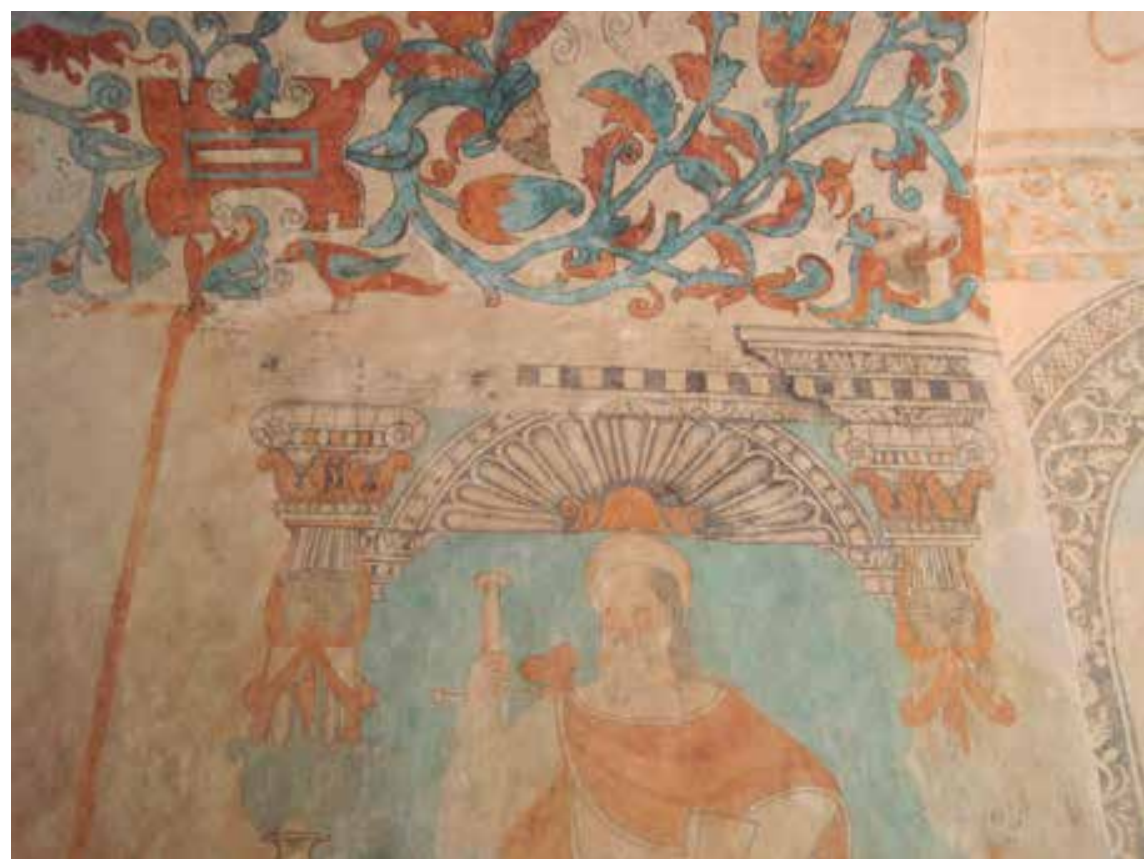

19. San Pablo, jamba este del vano de la puerta que comunica el claustro con la iglesia, convento de Santa Clara de Asís, Dzidzantún, Yucatán. Foto: Ana Raquel Vanoye Carlo, julio, 20I3. Secretaría de Cultura-INAH-Méx. "Reproducción autorizada por el Instituto Nacional de Antropología e Historia”.

ocupado por san Pablo, quien viste con una túnica blanca y un manto rojo, al igual que en el caso anterior, el fondo de la escena es celeste (fig. 19).

Aunque este par de pinturas comparte algunos rasgos con las que pertenecen a la primera decoración absidal, como la paleta de color, la forma de aplicarla, las composiciones arquitectónicas que enmarcan las escenas y algunos de sus elementos ornamentales también presenta semejanzas con los murales de la portería. Por ejemplo, el uso del punzón para realizar los trazos guía de las columnas: la línea vertical que funciona como eje y la serie de líneas paralelas y transversales a la anterior, que delimitan cada uno de los elementos que componen el fuste balaustrado de las columnas. Otra similitud es la línea roja que rodea ambas escenas, parecida a la que enmarca la escena de la Virgen de la portería (compárense las figs. 17 y 19). Por último, el ángulo izquierdo superior 
de la escena de san Pedro muestra un adorno al que decora, en los extremos superiores de los marcos de los caballetes localizados en los muros 4 y 5 del ábside de la iglesia: un par de listones entrelazados color sepia; al parecer, en este caso, el ornamento pende del extremo exterior de los capiteles. La presencia tanto de características que corresponden a la primera etapa, como de rasgos propios de la segunda indica su pertenencia al último conjunto.

En su conjunto la pintura mural de la etapa posterior indica que los nichos del vano de la puerta que comunica el claustro con la iglesia son las únicas composiciones arquitectónicas que aparecen en este segundo programa mural. Esto sugiere un cambio en la preferencia para presentar las escenas, al parecer, en esta etapa prevaleció la tendencia a utilizar marcos rectangulares, tal y como lo indican la línea roja que enmarca las escenas de san Pedro y san Pablo y los caballetes de los muros 4 y 5 del ábside.

\section{La tercera decoración del ábside (siglo XVIII) ${ }^{2 I}$}

El muro central de esta estructura es el único que no conserva pinturas correspondientes a la tercera decoración. ${ }^{22} \mathrm{~A}$ pesar de la ausencia de un elemento central en torno al cual organizar el tercer programa absidal, éste presenta simetría entre las composiciones de los muros 2 y 3 así como 4 y 5 (fig. 29). Tiene también algunas otras características, sobre todo materiales, que lo diferencian de las etapas anteriores, para ejecutarlo no se aplicaron nuevos enca-

2I. Los murales de esta etapa se trabajaron en el apartado "La pintura mural a colores" del capítulo titulado "El análisis de la pintura mural", en Vanoye Carlo, "Esbozo de la historia de la pintura mural virreinal de Yucatán," I2I-I34.

22. Durante la intervención de 20II, Garcés Fierros encontró restos de murciélagos y aves sobre el banco que se encuentra en la parte inferior de este muro y en las fisuras de las nervaduras. Lo anterior indica que esta pared sostuvo un retablo, porque esta fauna acostumbra vivir detrás de ellos. Con seguridad, tanto el guano como el excremento de paloma dańaron los encalados exteriores. Cuando el retablo se retiró del muro el daño fue evidente. Según el restaurador, el muro debía limpiarse pues constituía un foco de infecciones. Él pensaba que quienes habían retirado el retablo también habían tenido que desprender los encalados superficiales para eliminar los restos de esas sustancias y evitar que el deterioro continuara a los encalados interiores. Comunicación personal, Fernando Garcés Fierros, agosto de 20II. Lo anterior responde a la interrogante del porqué se observa en los muros 2, 3, 4 y 5 del ábside pintura correspondiente a diferentes periodos, mientras que en el muro I la pintura que sobrevive al parecer corresponde a la misma etapa. Comunicación personal, Fernando Garcés Fierros, junio de 2011. 


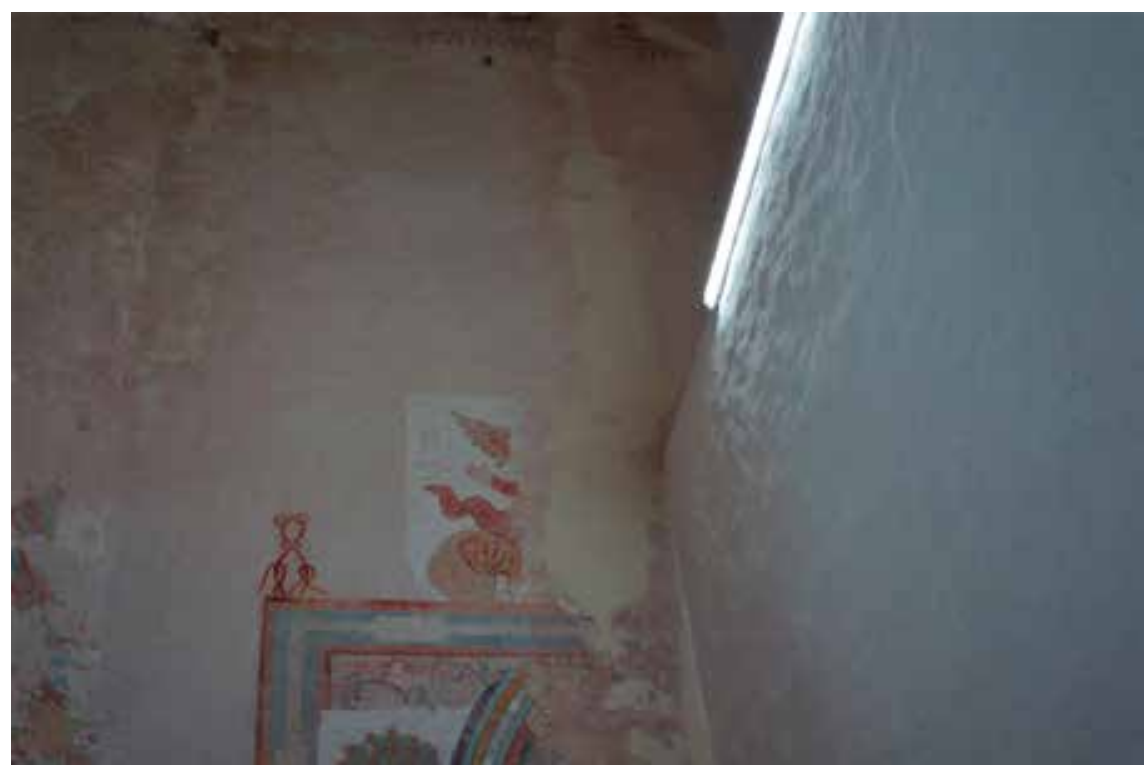

20. Esquina superior izquierda del caballete del muro 5. Foto: Ana Raquel Vanoye Carlo, julio, 20I2. Secretaría de Cultura-INAH-Méx. "Reproducción autorizada por el Instituto Nacional de Antropología e Historia”.

lados sobre los muros, sólo lechadas de cal y aunque proporcionan un soporte para recibir la nueva pintura, éstas no son tan durables como un encalado, a esto se debe que las pinturas se desprendan en pequeñas lajas en lugar de deslavarse como es el caso de la que corresponde a las etapas anteriores. Por otro lado, las lechadas no cubrieron por completo la decoración mural previa, lo cual permitió que ésta sirviera como una plantilla. ${ }^{23}$ Otra de sus características es el uso de una paleta de color más amplia, pues el pintor utilizó, además de negro, azul, rojo, y blanco, verde, amarillo, rosa, café y anaranjado. Asimismo, la línea con la cual se ejecutó el dibujo preliminar de la mayor parte de estas representaciones es negra, al igual que la empleada para los delineados finales.

23. El deterioro de los murales fue útil para mostrar que las columnas de los retablos de los muros 2 y 3, correspondientes a esta tercera decoración, se hicieron tomando como molde las arquivoltas que adornan las columnas, las cuales sostienen los arcos de medio punto pertenecientes a la primera etapa. Esto, aunado a que la decoración geométrica de círculos inscritos en cuadrados en rojo y azul no invade los arcos de medio punto, vuelve a sugerir que estos arcos se rescataron e incluyeron en el segundo programa pictórico absidal. 
DOI: http://dx.doi.org/10.22201/iie.18703062e.2016.109.2581

256

ANA RAQUEL VANOYE CARLO

La ampliación de la paleta de color permitió consolidar uno de los rasgos particulares de la pintura mural para esta región: la imitación de diferentes materiales de construcción y objetos. El desarrollo de este aspecto comenzó desde las etapas anteriores y se traduce para la primera decoración absidal en la imitación de elementos arquitectónicos monumentales en piedra, por eso toda la arquitectura está ejecutada en grisalla, y para la segunda, en la representación de las pinturas de caballete. Eventualmente, se imitaron una gran gama de materiales y objetos en pintura. Entre los materiales más representados se encuentra el mármol veteado aplicado sobre los elementos arquitectónicos a manera de franjas paralelas inclinadas en colores rosa, café y amarillo.

En general, los conventos franciscanos de la península de Yucatán ofrecen diversos ejemplos de objetos artísticos representados en pintura mural, entre los que destaca la serie de pinturas de caballete que adornan la sacristía del convento de San Pedro y San Pablo en Teabo, para las cuales incluso se pintó el clavo y la cuerda del que penden; por ejemplo, la pintura de caballete de santa Bárbara, que se encuentra en la portada de la iglesia de San Antonio de Padua en Izamal y que, muy probablemente, en su representación inicial fue una escultura, al igual que la Virgen del convento de San Francisco de Asís, en Conkal, ya que en ambas es posible observar, en la parte inferior, la peana sobre la cual se apoyaba el cuerpo de las santas, y los cuatro retablos que ornamentan el antiguo presbiterio de la iglesia del convento de Santa Clara que presentaré en este apartado.

Antes de abordarlos, mencionaré que el tamaño y la disposición de estos ejemplos respecto al recinto que los alberga indican algunos cambios en la relación entre la pintura mural y la arquitectura. En esta etapa, a diferencia de las dos anteriores, ambas juegan un papel más equilibrado: no hay una preeminencia de la pintura sobre la arquitectura. Los retablos, y en general todas las representaciones pictóricas, son mucho más pequeños, lo cual indica que la pintura mural no sustituye a la arquitectura ni se encarga de la reconstrucción del aspecto de los espacios interiores, sino que se coordina con ella para lograr su configuración.

Como ya lo mencioné, el muro central del ábside es un eje de simetría porque la composición en los dos muros de la derecha es igual a la de los dos de la izquierda. En los muros 2 y 3 se ejecutó un retablo que tiene composición y diseño similares, pero diferente temática; en ambos casos la estructura arquitectónica se localiza alrededor de la ventana que hay en ambos paramen- 
2I. Retablo mural, muro 3, ábside de la iglesia, convento de Santa Clara de Asís, Dzidzantún, Yucatán. Foto: Ana Raquel Vanoye Carlo, julio, 2013. Secretaría de Cultura-InaH-Méx.

"Reproducción autorizada por el Instituto Nacional de

Antropología e Historia”.

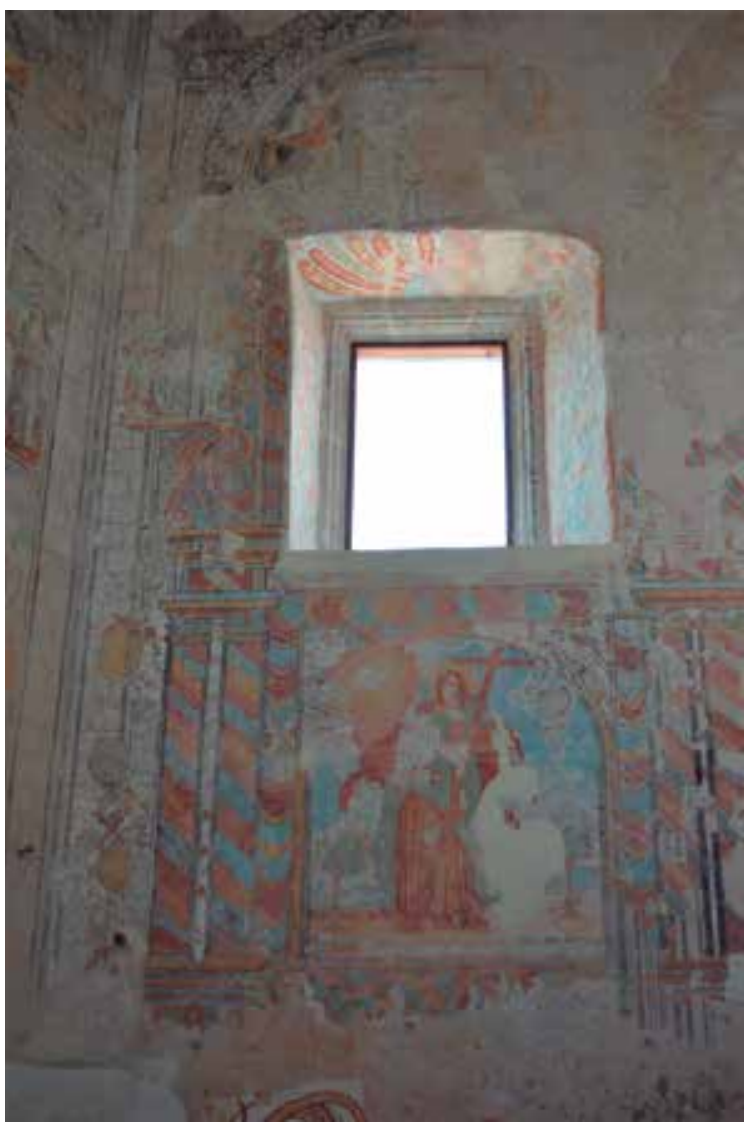

tos. El retablo del muro 3 (fig. 2I) está mejor conservado y, por eso, es conveniente comenzar la presentación de esta etapa con su descripción.

El elemento central de este retablo es una escena enmarcada por cuatro columnas veteadas, dos a cada lado; aunque la basa y el capitel guardan relación con el orden corintio, este último presenta algunas modificaciones: se han omitido los caulículos y algunas hileras de hojas de acanto y en su lugar se pintaron flores azules con centro café. Sobre cada par de columnas descansa un ábaco moldurado que también está decorado con franjas, imitando el mármol, además, tiene una característica muy peculiar: la perspectiva, lo cual, junto con el banco de cal y canto adosado al muro I, sugiere la presencia de un retablo de madera, del cual la pintura mural copió algunas de sus características. 
En la escena central se representó un arco apoyado sobre un par de soportes que en el interior alberga un personaje sin identificar. Al parecer no era prioridad del autor de esta pintura mostrar el arco, sino lo que contenía, debido a eso, los soportes laterales no son visibles: únicamente la moldura interior en amarillo. El diseño de este elemento permite apreciar parte del muro que se extiende sobre el arco y al cual también se le aplicó un tratamiento para imitar el mármol veteado. A la derecha del soporte izquierdo, y viceversa, se aprecia un rectángulo paralelo, negro y que se desvanece conforme se acerca a la clave del arco: es la representación del ancho de los soportes y del intradós del arco; su presencia indica que el autor trató de imprimir profundidad a la escena que contiene un personaje sin identificar vestido con una túnica amarilla y un manto verde y que porta en la mano izquierda una cruz de tamańo natural de la cual penden, en la parte central, unas llaves, en la derecha sostiene un libro. Detrás del personaje hay un paisaje, o al menos eso sugiere el color azul del fondo que tal vez representa el cielo y los árboles colocados a cada lado del personaje. La escena se delimitó como si se tratara de una pintura de caballete: usando un marco lobulado azul, ocre y sepia. Las características de esta representación muestran que, aunque los enmarcamientos arquitectónicos siguen formando parte de las composiciones murales, su diseño ha prescindido de los ornamentos e incluido el uso de paisajes.

El ángulo superior derecho de esta pintura muestra otro rasgo característico de esta etapa: presenta algunos faltantes que dejan al descubierto un fragmento de la pintura mural que está debajo, correspondiente a la primera decoración: el lado derecho de la venera, de gran tamaño, en grisalla descrita en el apartado correspondiente a la primera decoración del ábside. Este faltante pone en evidencia que el borde superior de la venera se utilizó como guía para trazar la moldura amarilla inferior del arco, éste es un indicio que señala que estos murales consideraron a las pinturas murales correspondientes a las etapas anteriores como guías de trazo. Más adelante señalaré otros ejemplos que refuerzan la afirmación anterior.

Hasta antes de 20II, lo anterior era todo lo que podíamos observar de este retablo, después de los procesos de intervención llevados a cabo por Garcés Fierros emergió la parte superior izquierda que corre paralela al vano de la ventana. Dicha sección es suficiente para poder reconstruir el aspecto que debió tener el retablo. Sobre el ábaco, del lado izquierdo, se apoya una ménsula invertida, del ángulo inferior izquierdo penden unos arreglos de flores, frutos y vainas, del lado derecho, se colocó una columna delgada y veteada, detrás 
hay una base sobre la cual descansa un ángel que sostiene una cartela ovalada, apergaminada con una leyenda ilegible en latín. De la parte superior de la columna emerge una banda ondulante que probablemente tenía otra leyenda en latín y la cual corre paralela al vano superior de la ventana. El final de esta banda probablemente se conectaba con una estructura muy similar a la que he descrito, paralela al lado derecho del vano de la ventana y que está perdida. En la etapa uno, arriba de esta banda y encima de la pintura de los ángeles sosteniendo una cartela descrita, se aprecia el brazo de un fraile franciscano, o al menos eso es lo que sugiere la ropa que porta, muy parecida a una túnica. La mano muestra la palma por lo cual al parecer el brazo está extendido. No hay ninguna conexión material entre este fragmento y el retablo descrito en los párrafos anteriores. Sin embargo, tal vez la representación superior del retablo del muro 2 pueda proporcionar la información faltante para establecer dicha relación.

La intervención de Garcés Fierros descubrió también, en el muro 2, la mitad derecha superior de una estructura arquitectónica similar a la descrita en el párrafo anterior. Antes de ese descubrimiento ya podía apreciarse el lado derecho inferior del retablo junto con algunos elementos de la escena central, por lo que actualmente disponemos de todo el lado derecho del retablo, que es similar en estructura, composición y color al que se localiza en el muro 3 (fig. 22).

La escena central es parecida a la del muro 3: aún son visibles algunos fragmentos de la moldura amarilla correspondiente a la parte inferior del arco y del soporte derecho sobre el que también corre paralela la franja negra que representa el ancho. En el interior de este arco se representó un personaje de pie, de frente y con los brazos extendidos en dirección al suelo, con la mano izquierda señala al sol mientras que con la derecha probablemente a la luna, pues aunque está en actitud de señalar, el mural presenta un faltante, el cual impide conocer a qué está haciendo referencia. Sin embargo, es muy probable que se trate de la luna porque es común la presencia conjunta de los dos astros. Tampoco es posible identificar los rasgos del rostro, pero el hábito café indica que se trata de un franciscano y nuevamente, como fondo se pintó un paisaje o al menos eso sugiere la presencia del fondo azul y los dos árboles que se encuentran, uno a cada lado del fraile. La existencia de la pintura anterior de san Francisco de Asís recibiendo los estigmas, correspondiente a la primera decoración insinúa que, quizá esta escena es una renovación de la representación anterior de este santo. Sólo sobrevive el lado derecho del marco de este caballete y al igual que el del retablo del muro 3, es lobulado. 
DOI: http://dx.doi.org/10.22201/iie.18703062e.2016.109.2581

260

ANA RAQUEL VANOYE CARLO

Los fragmentos de este retablo indican que su diseño es igual al descrito en los párrafos anteriores: paralela a la sección del marco existente se encuentran un par de columnas veteadas, de las cuales la basa y parte del cuerpo se han desprendido, lo que permite apreciar que las pilastras, que sostienen los arcos de medio punto correspondientes a la primera etapa, sobre todo las molduras que las decoran, se utilizaron como plantillas para trazar el nuevo retablo. Los capiteles de las columnas presentan modificaciones similares a las del retablo del muro 3: flores o mońos han sustituido los caulículos y las hojas de acanto de la hilera superior. En este retablo es posible apreciar que, entre las dos columnas se pintaron pequeñas flores formadas por cuatro pétalos azules y un centro rojo. Entre cada uno de los pétalos se agregó una hoja verde.

Sobre el ábaco, veteado y con perspectiva, que corona ambas columnas se aprecian a la derecha, la ménsula invertida y el arreglo floral y frutal que pende del vértice derecho; a la izquierda, la columna delgada y detrás de ella, la base sobre la cual se apoya un ángel que sostiene una cartela ovalada cuyo contenido es ilegible, en este caso es posible apreciar que viste una túnica roja, un manto azul, sus alas también son azules y porta en la mano derecha una palma. La parte superior de la columna es el arranque de la banda blanca cuyo extremo se conecta con una estructura igual a la descrita y la cual corre paralela al lado izquierdo del vano de la ventana.

La franja está decorada, en sus extremos, por dos líneas delgadas: la exterior es ocre y la interior azul, y encima de ella se encuentra una representación de un rey, la corona, la capa y el cetro que porta en la mano izquierda se conservan en buen estado, al igual que la vestimenta, que incluye camisola, calzas, jubón, greguescos y collar (fig. 6). El personaje aparece de pie sobre un piso café, en realidad se trata de una mancha oscura que sigue la forma de la banda superior del retablo, y rodeado de arbustos que tienen frutos café rojizo. Al parecer, esta composición coronaba el retablo. Tal vez, una similar remataba también el retablo del muro 3 y el lugar del rey estaba ocupado por el franciscano del que sólo sobrevive la mano derecha.

De acuerdo con esta idea, la posición de los temas en los retablos está invertida, es decir, en el del muro 2, la escena superior es un rey, mientras que la inferior es un franciscano y para el caso del muro 3, en la escena superior aparece un franciscano y en la inferior debe corresponder a Jesús, que es un rey. Este recurso de inversión lo emplearon los franciscanos para señalar coincidencias entre su origen y desarrollo y el de Jesús y su familia y con ello dotarlos de legitimidad. 


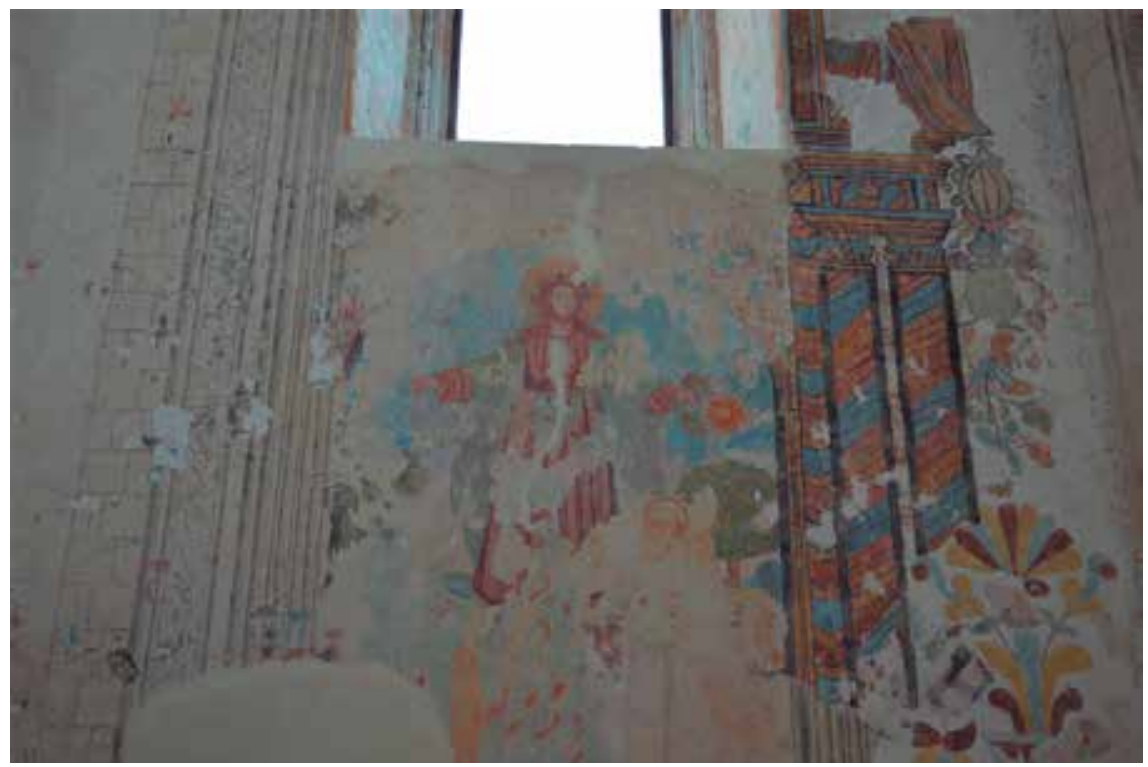

22. Sección inferior del retablo del muro 2 del ábside de la iglesia, convento de Santa Clara de Asís, Dzidzantún, Yucatán. Foto: Ana Raquel Vanoye Carlo, julio, 2013. Secretaría de Cultura INAH-Méx. "Reproducción autorizada por el Instituto Nacional de Antropología e Historia".

Las características de los retablos de los muros 4 y 5 refuerzan la idea anterior y, además, revelan la existencia de una relación entre los cuatro elementos arquitectónicos. El primer retablo está en el muro 4, a la izquierda del que he descrito en el párrafo anterior, si bien sólo sobrevive la mitad derecha; la izquierda quedó debajo de la pared con la pilastra que apuntala la bóveda de nervaduras. Probablemente se trata de la genealogía de Jesús (fig. 23). Está formado por dos cuerpos de diferente altura y el ático; la altura del inferior es aproximadamente el doble del superior. Dentro de estas estructuras hay medallones: dos en el cuerpo inferior, dispuestos en columna, uno en el superior y otro en el ático. La composición que albergan los medallones es muy similar; en ellos se colocaron los bustos de cuatro personajes vestidos con mantos y túnicas de diferentes colores y que portan una corona. Debajo de cada uno hay un óvalo blanco sobre el que se escribieron textos en latín, ahora perdidos (fig. 24b). Arriba de los personajes hay una filacteria blanca cuyos textos latinos también se han borrado, a la derecha de cada figura hay un pequeño rombo blanco, 
DOI: http://dx.doi.org/10.22201/iie.18703062e.2016.109.2581

262

ANA RAQUEL VANOYE CARLO

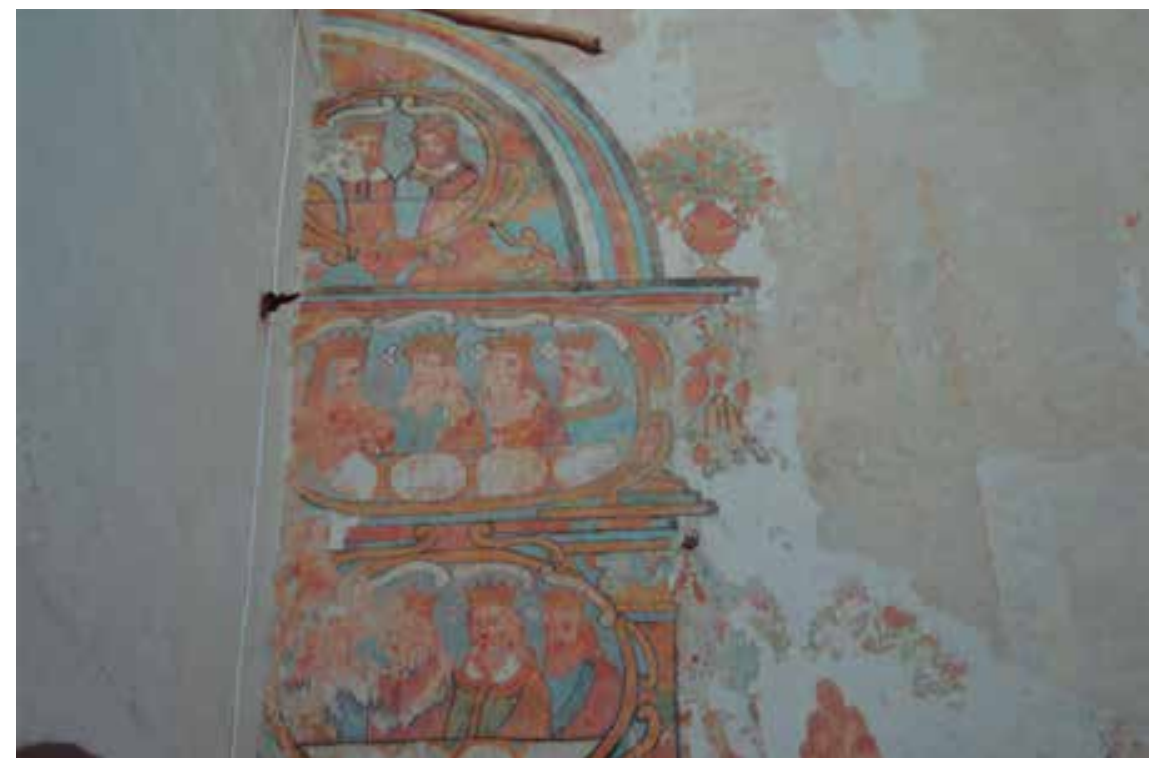

23. Retablo mural, la genealogía de Jesús, muro 4 del ábside de la iglesia, convento de Santa Clara de Asís, Dzidzantún, Yucatán. Foto: Ana Raquel Vanoye Carlo, julio, 20I3. Secretaría de Cultura-INAH-Méx. "Reproducción autorizada por el Instituto Nacional de Antropología e Historia”.

en cuyo interior todavía es posible distinguir la letra $m$ mayúscula. El diseño del medallón que se encuentra en el ático es un poco diferente pues no tiene ninguno de los elementos que, en el caso anterior, albergan los textos y además, sólo aparecen dos personajes que presentan las características señaladas.

El ático tiene forma semicircular y está decorado con un conjunto de manchas rojas, anaranjadas y azules que indican la imitación de mármol veteado; el borde está adornado con molduras cuyos colores son, de la interior a la exterior, negro, blanco, azul, rojo, ocre y azul con negro, sobre la estría blanca hay fragmentos de palabras en latín (fig. 24c). Este frontón descansa sobre un dintel de cuatro molduras cuyos colores son, desde la superior, negro, azul, rojo y ocre, en el extremo derecho se colocó un copón de flores que flanquea el ático. La parte derecha de esta estructura se apoya sobre una columna veteada de la que sólo se aprecia la base y el capitel, porque el cuerpo queda detrás de uno de los medallones, es decir, su altura es la misma que la de esta última estructura. Tanto éste como la pequeña columna descansan de nuevo sobre un 
dintel de cuatro molduras cuyos colores son, comenzando desde la superior: azul, ocre, ocre y café, azul y ocre. Del extremo derecho de la inferior penden unos arreglos florales y frutales. El cuerpo descrito anteriormente descansa sobre otro de composición similar, pero de doble altura.

En el muro 5 también sobrevive la mitad izquierda de un retablo. La derecha quedó debajo de la pared que apuntala la bóveda de nervaduras. Este retablo, al parecer, trata de la genealogía de los franciscanos y comparte la paleta cromática, la composición plástica y la arquitectónica con el retablo descrito en el párrafo anterior. Dentro de los medallones se representaron bustos de personajes franciscanos: cuatro que forman parte de los cuerpos arquitectónicos y dos que están en el ático (fig. 24a).

La posición encontrada de los retablos (fig. 2) indica, una vez más, la presencia de un ejercicio de legitimización de los orígenes de los franciscanos mediante su equiparación con los de Jesús. La serie de manchas y franjas paralelas, simulando mármol veteado, que sobrevive en la parte superior del vano de la puerta que comunica el claustro con la nave de la iglesia sugiere que, posiblemente, este recinto exhibió una decoración parecida.

El convento de San Miguel Arcángel, en Maní, también alberga un conjunto extenso de murales ejecutados con una paleta de color similar a la considerada en este apartado. Las similitudes son suficientes para afirmar que las que abordo aquí no se emplearon de manera exclusiva en el convento de Santa Clara de Asís y las diferencias permiten asegurar que existió un conjunto muy amplio de posibilidades para decorar los muros de los conventos del que sobrevive una pequeña parte.

Entre las semejanzas están las franjas inclinadas, simulando mármol veteado, que aún es posible apreciar en algunas estructuras arquitectónicas, como las columnas de la portería en colores rojo, azul y ocre.

Las pinturas murales de la iglesia se encuentran en el intradós de los dos arcos formeros de la iglesia más próximos al presbiterio. Actualmente, ambos albergan retablos: el que se localiza en el muro sur está dedicado a san Antonio de Padua y el del muro norte, a La Dolorosa. Las pinturas que se encuentran en el intradós de este último son las siguientes: en la parte central una representación de Cristo niño parado sobre el mundo, hacia abajo, al este, hay otras dos pinturas, en la más cercana a la anterior se ejecutó a san Diego de Alcalá y el Milagro del Pozo y debajo de ésta, a José de Arimatea recibiendo el cuerpo de Jesús. Al oeste, también hay dos escenas, junto a la representación del Niño Jesús parado sobre el mundo se encuentra una de san Diego de Alcalá y el Milagro del Hor- 
DOI: http://dx.doi.org/10.22201/iie.18703062e.2016.109.2581

264

ANA RAQUEL VANOYE CARLO

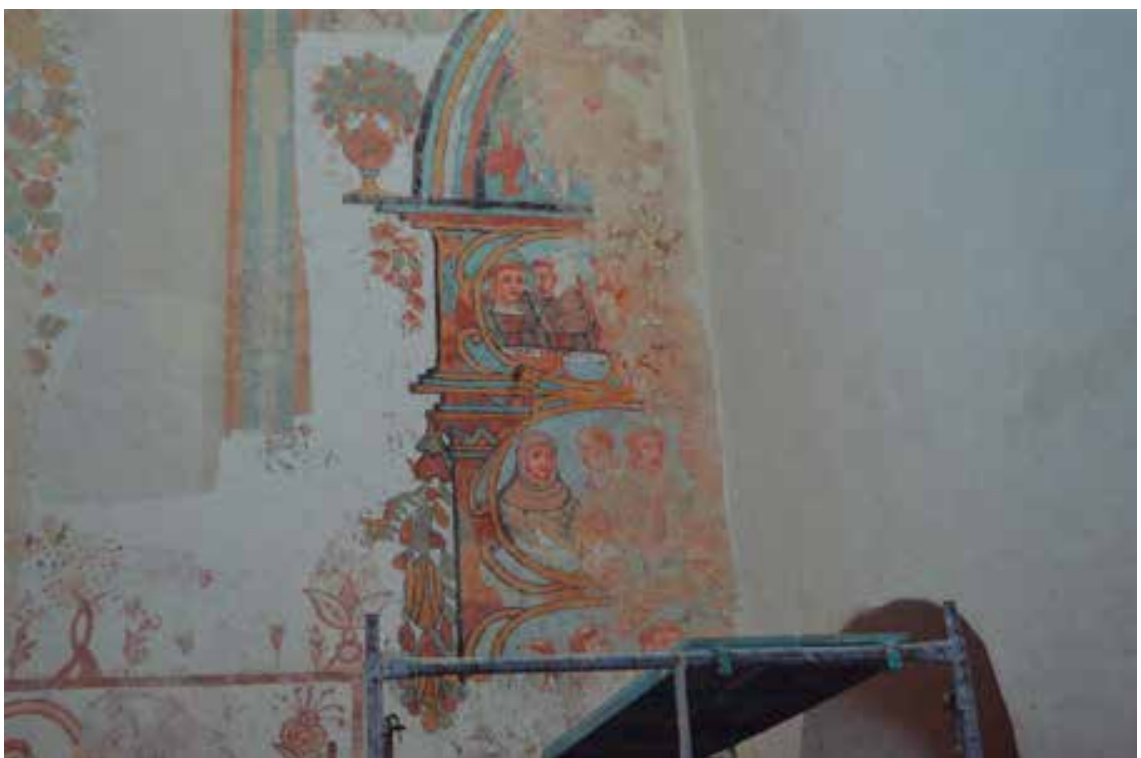

24. a)Retablo mural, probablemente la genealogía de san Francisco, muro 5 del ábside de la iglesia, convento de Santa Clara de Asís, Dzidzantún, Yucatán.

no, junto a ésta se pintó un entierro franciscano del que no es posible obtener información sobre la identidad del personaje. Unas líneas gruesas, amarillas, separan cada una de las escenas anteriores.

La presencia conjunta de las escenas del entierro franciscano y del Descendimiento nuevamente vuelve a sugerir la tendencia de los menores a encontrar en la vida de Jesús la legitimización de su origen y su misión. La presencia de estos ejercicios en las iglesias de Dzidzantún y Maní señalan que éste era el recinto adecuado para llevarlos a cabo.

Toda la decoración mural que sobrevive en el arco formero del muro sur de la iglesia también se localiza en el intradós, sin embargo, y a diferencia del anterior, sólo sobreviven las tres escenas centrales, las dos de los extremos se han perdido. Al igual que en el caso previo, en el centro hay una representación de Cristo niño parado sobre el mundo, al oeste se ve a san Antonio de Padua y el Milagro de la Mula, y al este a san Antonio de Padua discutiendo con un par de herejes. Ambas escenas ocupan el mismo lugar que las representaciones de los milagros de san Diego de Alcalá, por lo cual, quizá las dos pinturas perdidas también cumplan la relación entre las genealogías de 
DOI: http://dx.doi.org/10.22201/iie.18703062e.2016.109.2581

MURAL DEL CONVENTO DE SANTA CLARA DE ASÍS

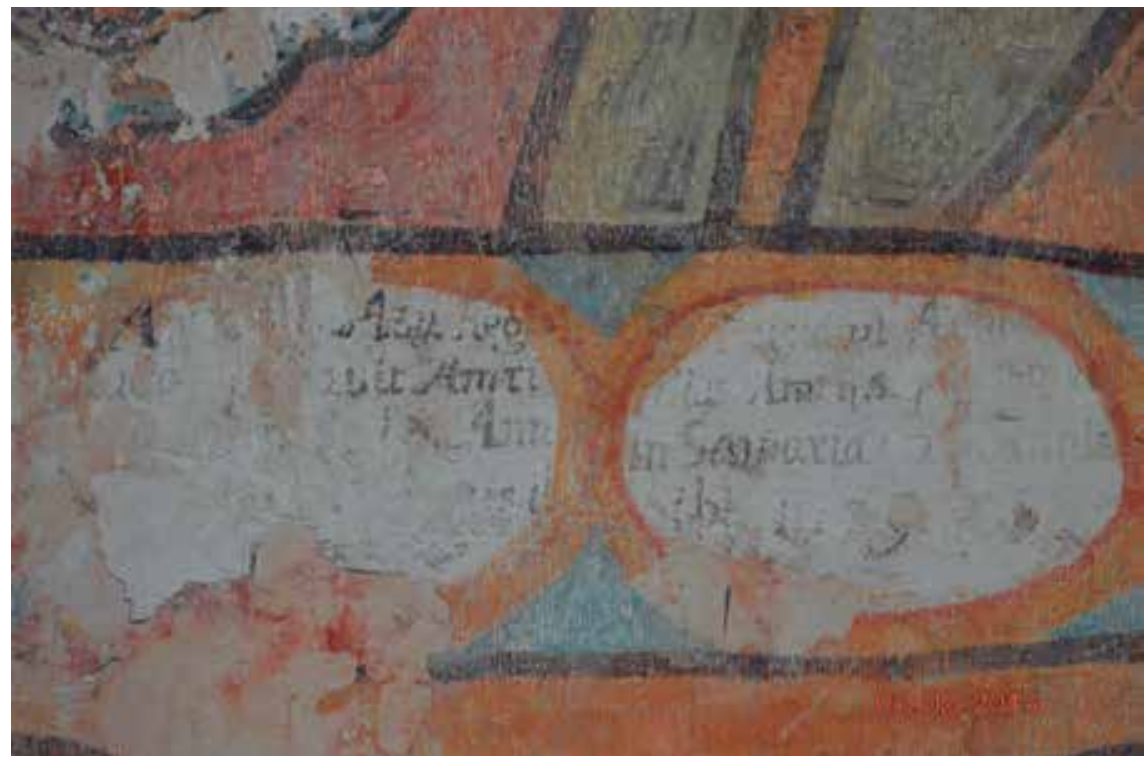

b) Detalle de los óvalos que se encuentran debajo de cada uno de los reyes.

c) Detalle de las molduras que decoran el frontón curvo del retablo. Fotos: Ana Raquel Vanoye Carlo, julio, 2013. Secretaría de Cultura-INAH-Méx. "Reproducción autorizada por el Instituto Nacional de Antropología e Historia”.

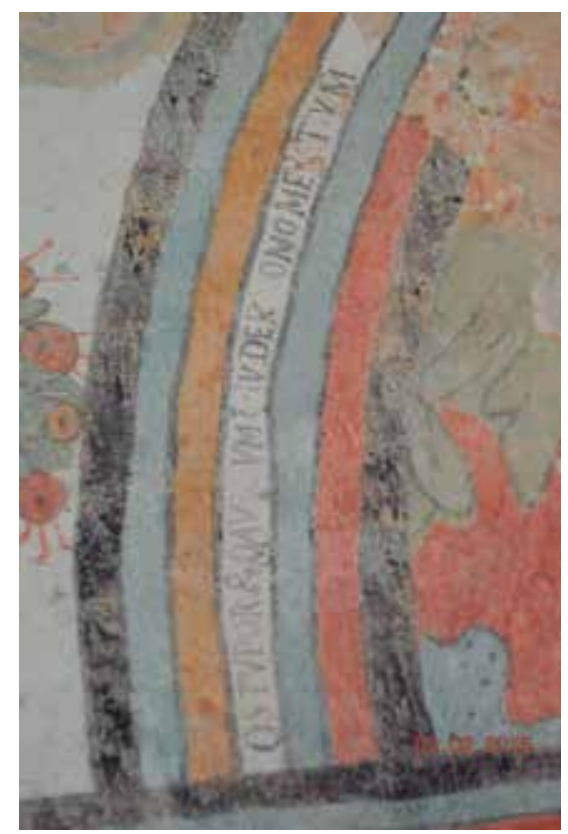


DOI: http://dx.doi.org/10.22201/iie.18703062e.2016.109.2581

Jesús y san Francisco de Asís. De este modo, el tema de una podría ser un pasaje de la vida de Jesús y, la otra podría contener una experiencia de la vida de este santo franciscano.

Probablemente las decoraciones del ábside de la iglesia de Dzidzantún y las de los arcos formeros de la iglesia de Maní eran complementarias. El uso de la misma paleta de color, el empleo de paisajes como los fondos de las escenas y la relación mesurada entre la pintura y la arquitectura así lo sugieren. Tal posibilidad indica que la pintura mural incluida en esta etapa esboza el aspecto que pudo haber exhibido cualquier iglesia.

\section{La cuarta decoración del ábside (siglo XIX, principios del siglo XX)}

La última decoración mural está integrada solamente por elementos de ornato; no hay escenas de la vida de los santos; para su diseño se eligió un motivo que se repite a lo largo de todos los paramentos tal y como lo indica la presencia de fragmentos correspondientes a este tipo de adornos en todos los muros del ábside.

La primera decoración se trata de una cenefa, que tiene aproximadamente un metro de altura y sus elementos han sido delineados en color ocre y rellenados con amarillo. El diseño es una cinta ondulante que funciona como un eje alrededor del cual se articulan diversas formas como lazos, pequeños árboles, hojas, flores y hostias y que está enmarcada por un rectángulo sepia sobre el cual se apoyaron de manera alterna pequeños árboles y flores (fig. 25).

Debajo de esta capa se aprecian los restos de otra pintura decorativa, se trata de flores hechas a base de figuras geométricas: los pétalos, el tallo y las hojas se representaron utilizando triángulos azules y amarillos, para el centro, de color sepia, se empleó un círculo ejecutado con un punzón. Las flores que se localizan en la parte inferior del muro descansan sobre una cenefa compuesta por dos franjas paralelas, pintadas, por segmentos rectangulares, en diferentes colores, entre los que destacan amarillo, ocre, azul claro y oscuro (fig. 5).

La tercera decoración es la más reciente, sólo los muros de la iglesia y del claustro conservan rastros de ella, se ejecutó en azul marino y naranja. En el primer recinto el azul se aplicó como el guardapolvo, el cual se remató con una franja delgada y naranja, sobre él se delinearon en azul unas cartelas hexagonales y alargadas que contienen seis racimos de uvas del mismo color. En el claustro, cada uno de los arcos se decoró con una franja azul gruesa y encima de ésta, una delgada en color naranja. 


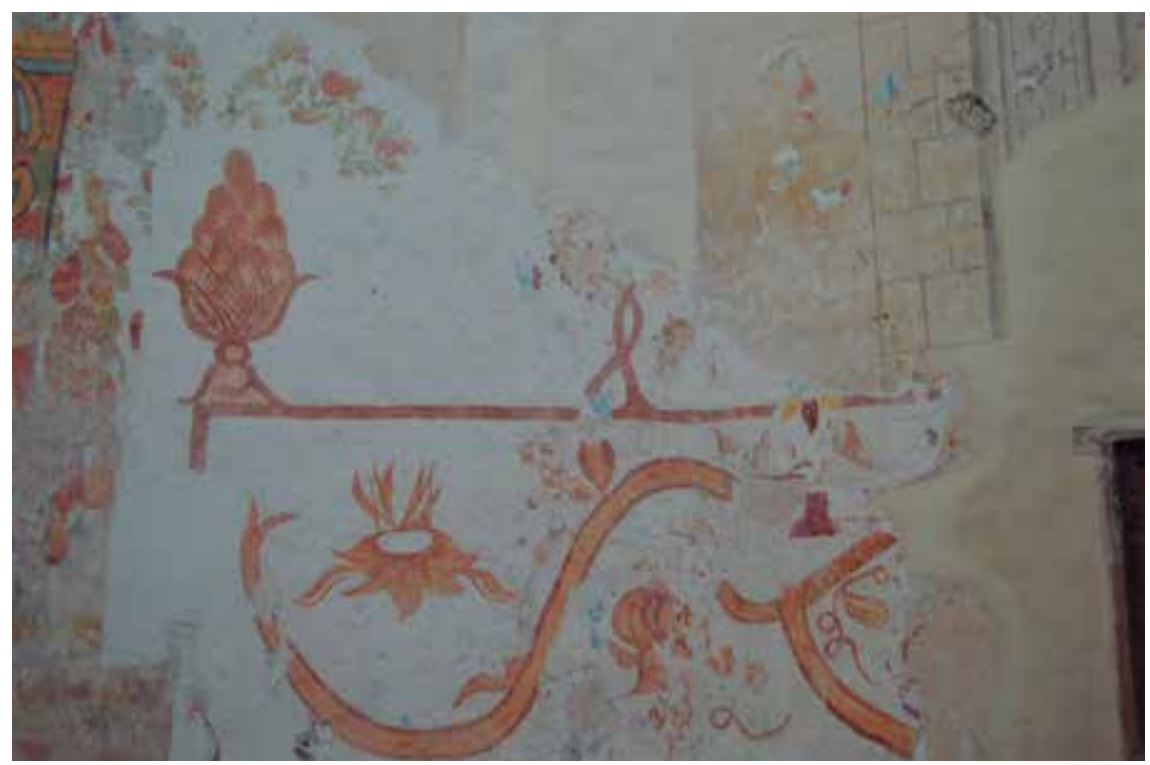

25. Cenefa, ábside de la iglesia, convento de Santa Clara de Asis, Dzidzantún, Yucatán. Foto: Ana Raquel Vanoye Carlo, julio, 20I3. Secretaría de Cultura-INAH-Méx. "Reproducción autorizada por el Instituto Nacional de Antropología e Historia”.

La anterior es la pintura mural que he podido describir y organizar dentro de la secuencia, sin embargo, no es toda la que sobrevive en el convento de Santa Clara de Asís, abajo de los cuatro retablos descritos en la tercera etapa hay una gran cantidad de fragmentos que indican que existieron otras decoraciones murales de las cuales ya no es posible obtener información que permita incluirlas en la secuencia. Sin embargo, las pinturas descritas hasta aquí son suficientes para explorar algunas líneas de investigación.

La ventaja principal que ofrece la secuencia es por un lado, la posibilidad de establecer relaciones entre las pinturas que forman parte de ella y las que provienen de otros edificios religiosos localizados también en el norte de la península de Yucatán. La construcción de estas relaciones es útil para inferir la persistencia en las características de ciertas tendencias decorativas, por ejemplo, la paleta de color, los elementos decorativos y los cambios en la relación entre la arquitectura y la pintura mural. Por el otro, permite determinar cuáles son los murales que no guardan relación con la secuencia propuesta y estimar su proporción. Por lo que la organización de los murales del con- 
DOI: http://dx.doi.org/10.22201/iie.18703062e.2016.109.2581

vento de Dzidzantún constituye, en última instancia, el primer paso para el ordenamiento y la definición de los rasgos particulares de la pintura mural franciscana del norte de la península de Yucatán.

La descripción de las pinturas murales presenta sus propios alcances; constituye un testimonio del aspecto que exhibían antes de la restauración de 20II, pues aunque este procedimiento favoreció la construcción de la secuencia al revelar nuevos murales, también determinó grandes cambios en el aspecto de la pintura debido a que los faltantes de los diferentes encalados se restituyeron y la capa pictórica se reintegró. Actualmente, ya no es posible apreciar desniveles en las pinturas murales, lo que impide apreciar diferentes momentos de su ejecución y construir propuestas alternas a la que este trabajo presenta.

A su vez, las descripciones de estos murales permiten plantear problemáticas relacionadas con su datación, con la definición de los cambios en los patrones preferidos para representarlos, así como con su relación con otros objetos artísticos y su papel en los fenómenos antropológicos.

\section{Conclusiones}

En general, muy pocos conventos del norte de la península de Yucatán conservan pintura mural, la cual con frecuencia está muy deslavada o fragmentada. El caso del convento de Santa Clara de Asís fue excepcional porque, hasta antes de la restauración de 20iI, conservaba una gran cantidad de murales sin intervenir y sus encalados presentan faltantes. Estas características permitieron definir diferentes etapas de ejecución, es decir, la pintura fue óptima para la reconstrucción de una secuencia que organizara las pinturas desde las más antiguas hasta las más recientes. Este estudio propone una secuencia y también expone los argumentos que sostienen su validez, muchos de ellos proporcionados por la información que surgió durante los procesos de desencalamiento, limpieza y consolidación de la intervención de 20II, los cuales permitieron la identificación de nuevos rasgos materiales y plásticos que ayudaron a definir algunas particularidades de la secuencia propuesta y afinar algunas otras ya establecidas.

Por un lado, la organización y la presentación de la pintura mural en cuatro etapas preservan los rasgos que caracterizaron estos objetos antes de la reintegración de su capa pictórica y contrarrestan parcialmente el aspecto homogéneo proporcionado por este proceso. Por otro, también constituyen una base indispensable a partir de la cual es posible desarrollar otro tipo de estu- 
dios, por ejemplo, los que se centran en establecer la relación existente entre la pintura mural y la arquitectura, o aquellos cuyo objetivo es inferir, a partir de los fragmentos existentes, y en la medida de las posibilidades, el aspecto que debió haber exhibido el ciclo pictórico completo. También representan un antecedente sólido para la investigación relacionada con la historiografía.

La existencia de estas etapas organizadas de acuerdo al orden de ejecución de la pintura mural también muestra que es necesario ampliar los estudios sobre la materialidad de la pintura mural, sobre todo los correspondientes a las primeras etapas y por último indica que existe una gran cantidad de pintura mural que queda fuera de ella y para la cual son necesarias nuevas aproximaciones bajo las cuales sea posible estudiarla. \$

N.B. Este trabajo ha sido posible gracias al apoyo y asesoría de muchos especialistas, en particular quiero reconocer a Marco Tulio Peraza Guzmán (FA-UADY), quien ha coordinado gran parte del trabajo de campo llevado a cabo en los conventos franciscanos del norte de la península de Yucatán; a Elena Isabel Estrada de Gerlero (IIE-UNAM), quien numerosas veces ha identificado los aspectos más relevantes de esta investigación y aportado ideas para su desarrollo; y al arquitecto Javier Martínez Burgos (FA-UNAM) por transmitirme su conocimiento e ideas sobre los conventos franciscanos localizados en el centro de México. 
DOI: http://dx.doi.org/10.22201/iie.18703062e.2016.109.2581

Anexo documental 
26. Aspecto actual de la pintura mural del ábside de la iglesia, convento de Santa Clara de Asís, Dzidzantún, Yucatán. Dibujo: Ana Raquel Vanoye Carlo, junio, 2013

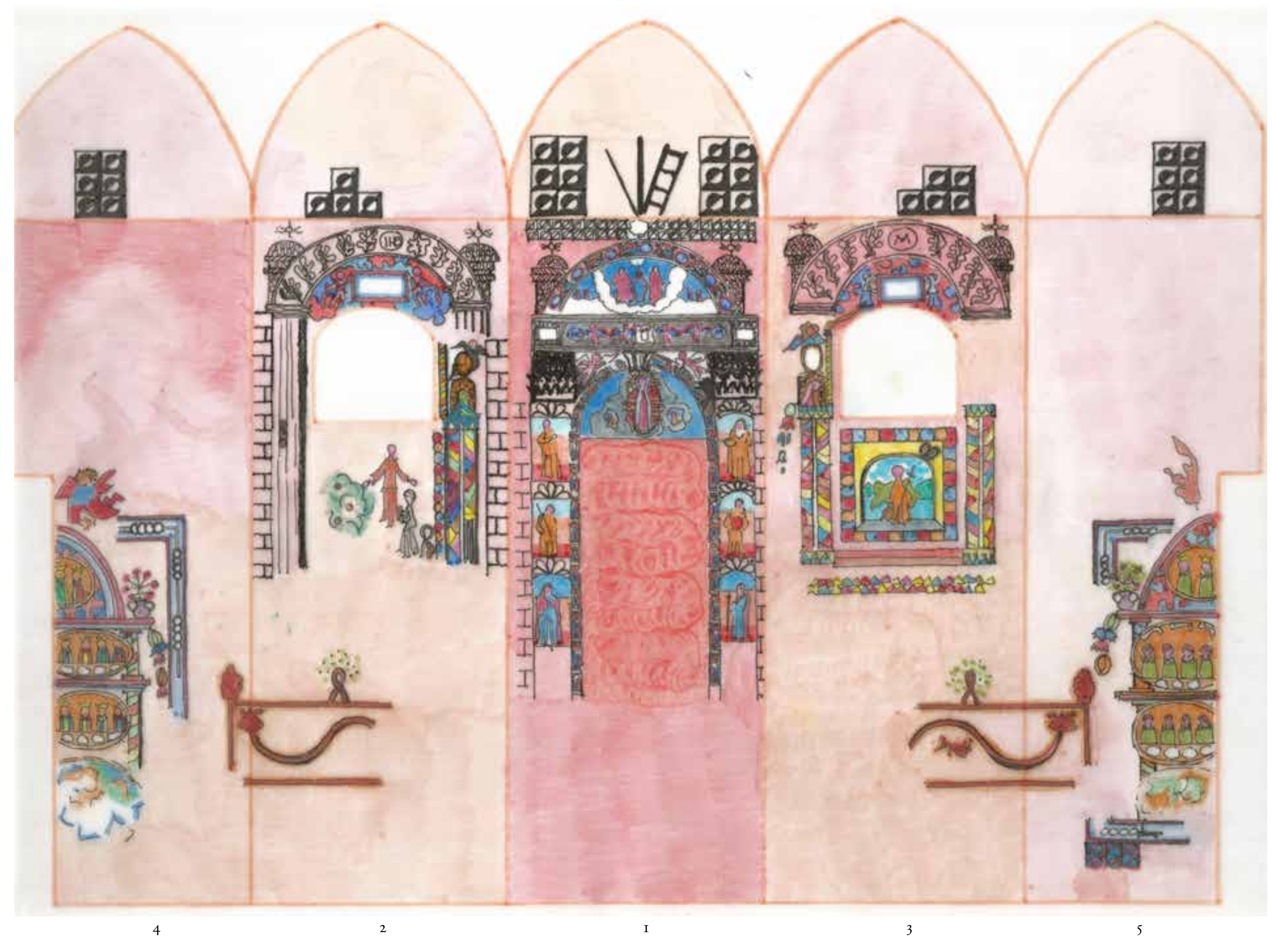




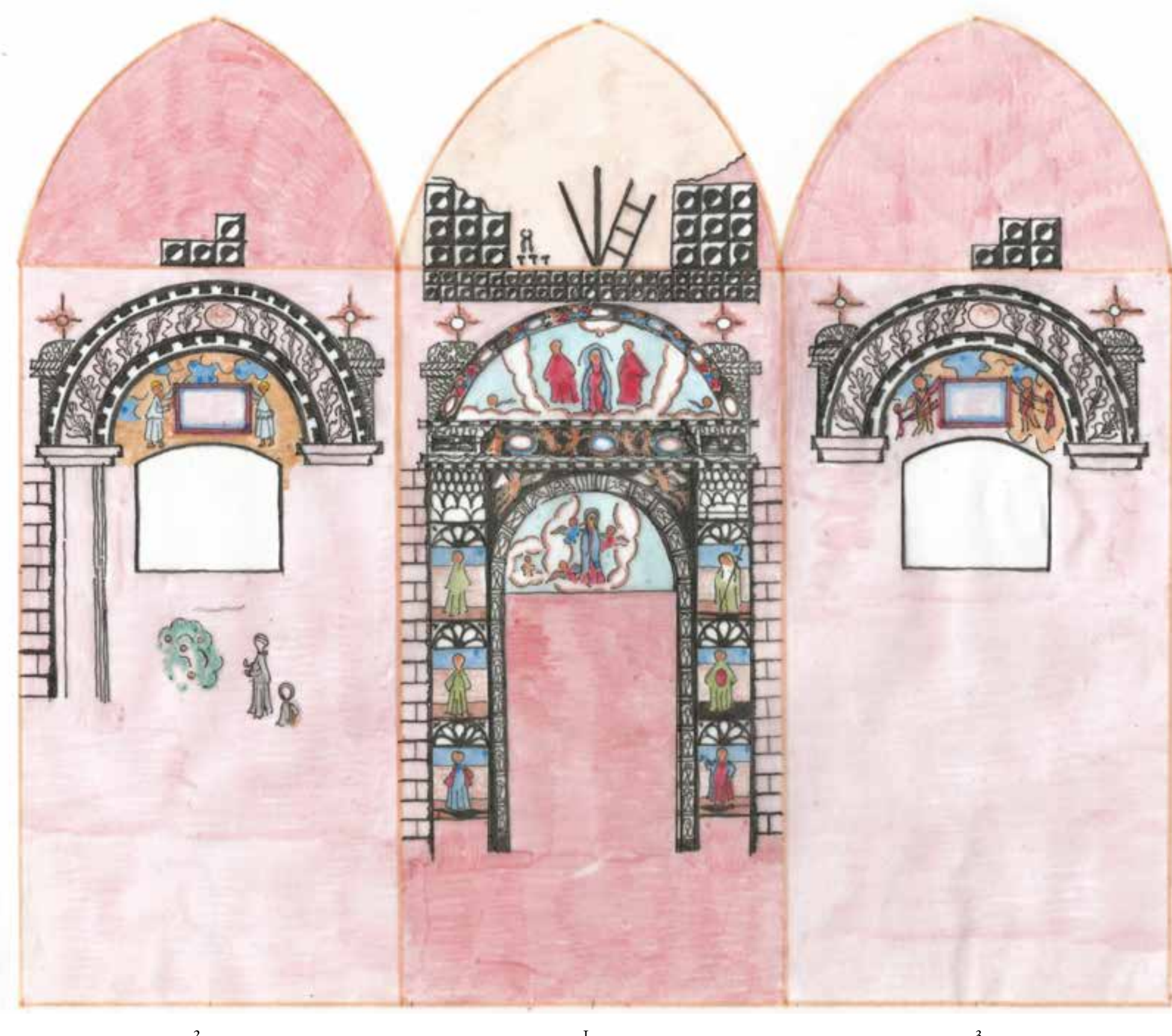

27. Primera decoración del ábside de la iglesia (I 575-I 700), convento de Santa Clara de Asís, Dzidzantún, Yucatán. Bosquejo: Ana Raquel Vanoye Carlo, junio, 2013. 


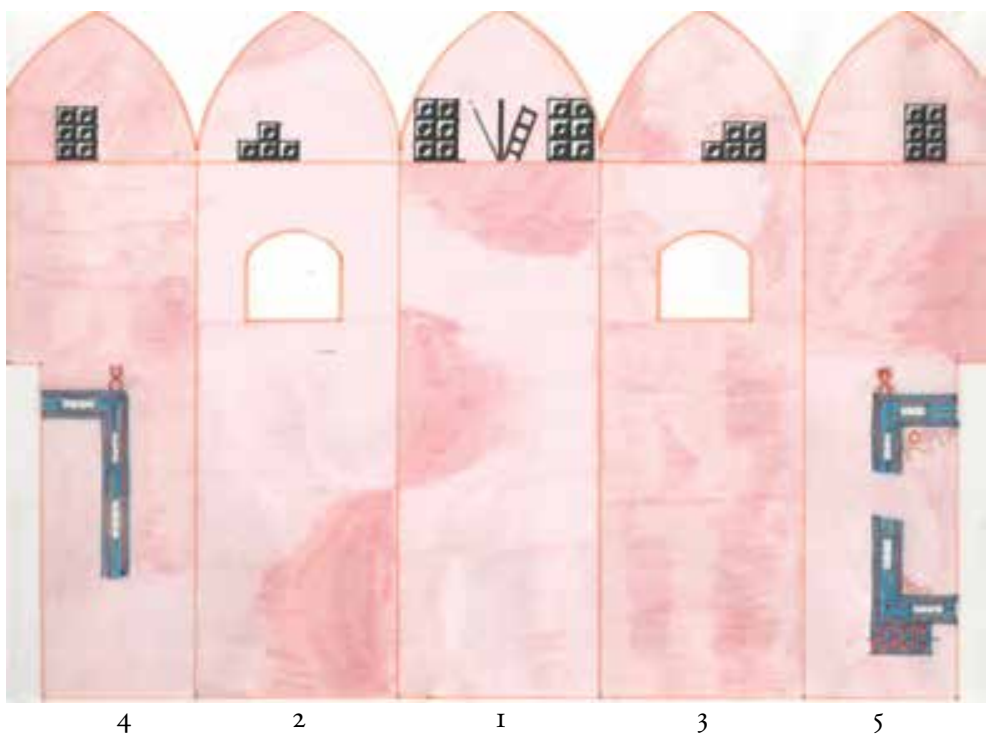

28. Segunda decoración del ábside de la iglesia (I625-1700), convento de Santa Clara de Asís, Dzidzantún, Yucatán. Dibujo: Ana Raquel Vanoye Carlo, julio, 2012.

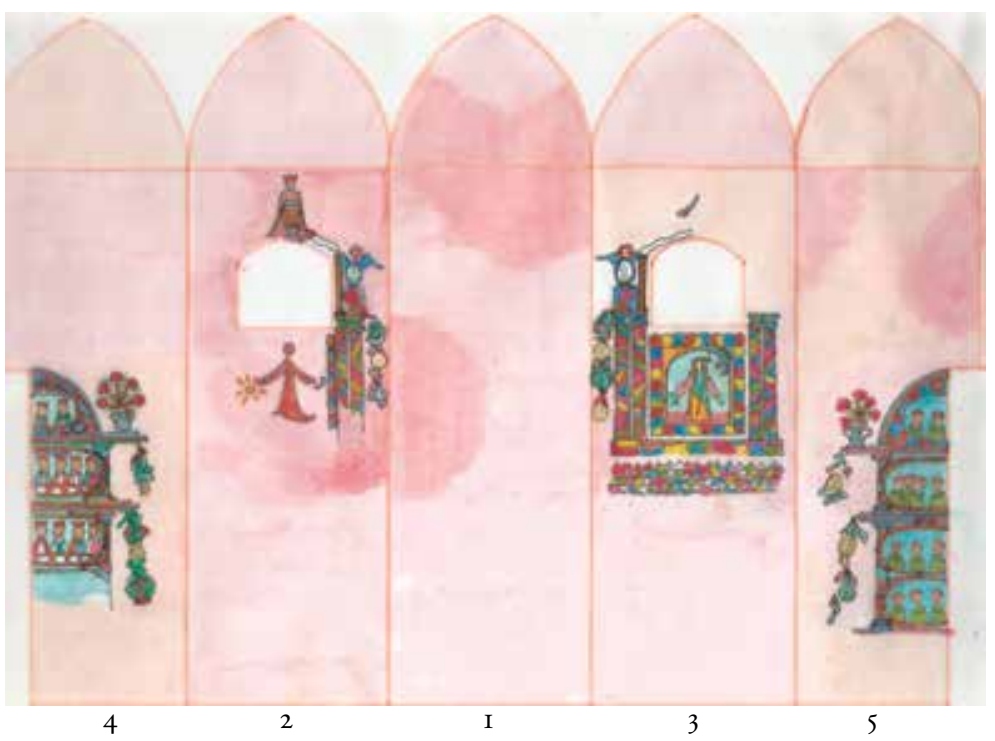

29. Tercera decoración del ábside de la iglesia (siglo XVIII), convento de Santa Clara de Asís, Dzidzantún, Yucatán. Dibujo: Ana Raquel Vanoye Carlo, julio, 2012. 